82
CONTRACTOR REPORT
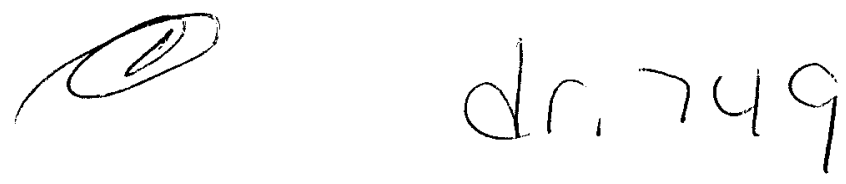

SAND82-7027

Unlimited Release

UC $-66 \mathrm{c}$

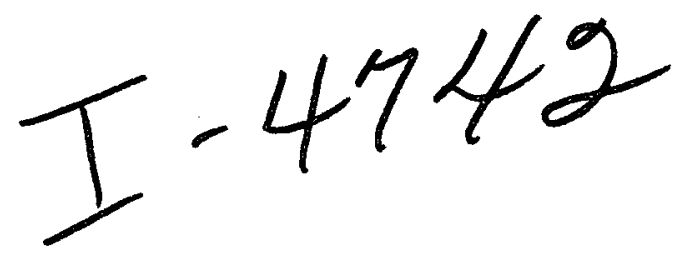

\title{
Diesel Exhaust-Gas Purification
}

\section{System}

MASTER

SAND--82-7027

DE82 019808

Brian J. Doherty

Foster-Miller, Inc.

350 Second Avenue

Waltham, MA 02254

Prepared by Sandia National Laboratories Albuquerque, New Mexico 87185 and Livermore, California 94550 for the United States Department of Energy

under Contract DE-AC04-76DP00789

Printed July 1982 


\section{DISCLAIMER}

This report was prepared as an account of work sponsored by an agency of the United States Government. Neither the United States Government nor any agency Thereof, nor any of their employees, makes any warranty, express or implied, or assumes any legal liability or responsibility for the accuracy, completeness, or usefulness of any information, apparatus, product, or process disclosed, or represents that its use would not infringe privately owned rights. Reference herein to any specific commercial product, process, or service by trade name, trademark, manufacturer, or otherwise does not necessarily constitute or imply its endorsement, recommendation, or favoring by the United States Government or any agency thereof. The views and opinions of authors expressed herein do not necessarily state or reflect those of the United States Government or any agency thereof. 


\section{DISCLAIMER}

Portions of this document may be illegible in electronic image products. Images are produced from the best available original document. 
Issued by Sandia National Laboratories, operated for the United States Department of Energy by Sandia Corporation.

NOTICE: This report was prepared as an account of work sponsored by an agency of the United States Government. Neither the United States Government nor any agency thereof, nor any of their employees, nor any of their contractors, subcontractors, or their employees, makes any warranty, express or implied, or assumes any legal liability or responsibility for the accuracy, completeness, or usefulness of any information, apparatus, product, or process disclosed, or represents that its use would not infringe privately owned ights Reforence herein to any apecific commercial product process or aights. Refer, or service by trade name, trademark, manufacturer, or otherwise, does not necessarily constitute or imply its endorsement, recommendation, or favoring by the United States Government, any agency thereof or any of their contractors or subcontractors. The views and opinions expressed herein do not necessarily state or reflect those of the United States Government, any agency thereof or any of their contractors or subcontractors.

Printed in the United States of America Available from

National Technical Information Service

U.S. Department of Commerce

5285 Port Royal Road

Springfield, VA 22161

NTIS price codes

Printed copy: A04

Microfiche copy: AO 
SAND $82-7027$

Unlimited Release

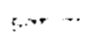

Category UC-66c

\title{
MOTICE
}

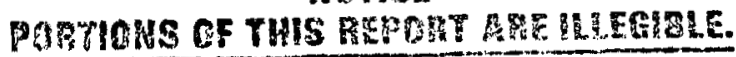

iv tas been reprofuces frowi the bast available copy to permit the broadest possible availability.

\section{MN ONE}

DIESEL EXHAUST-GAS

PURIFICATION SYSTEM

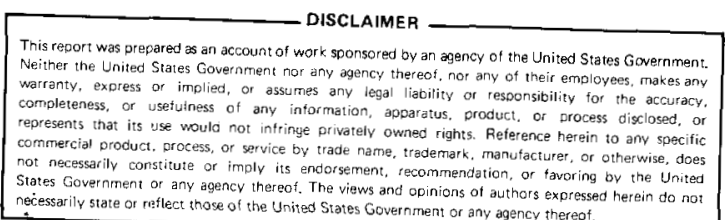

necessarily stote or

\begin{abstract}
Brian J. Doherty
Foster-Miller, Inc.

350 Second Avenue

Waltham, MA 02254
\end{abstract}

\section{ABSTRACT}

The design of a diesel exhaust gas purification system is presented. It will provide 2000 scfin of dry, anerobic gas (essentially nitrogen) for use in air drilling operations where drill pipe corrosion is a problem, such as geothermal applications. The system is operable in the field and may be transported via highways. It will operate at ambient temperatures up to $110^{\circ} \mathrm{F}$ and requires no water - diesel fuel is used to combust excess oxygen and to generate electricity for the system. Gas production costs, including capital amortization, operations, fuel and maintenance (for reasonable utilization) are about $\$ 1.50 / 1000$ scf. 
TABLE OF CONTENTS

Section No.

Page No.

EXECUTIVE SUMMARY

1

2

2.1

2. 2

2.3

2. 3.1

2. 3.2

2.3 .3

2.3 .4

2. 4

2. 4.1

2. 4.2

2.4 .3

2. 5

2.6

2.7

2. 7.1

2.7 .2

2.7 .3

2.8

2. 8.1

2. 8.2

3

3.1

3.2
INTRODUCTION

SYSTEM DESIGN CONSIDERATIONS

Basic Process

Diesel Engine Interface Requirements

Catalyst System Design Considerations

Catalyst Operating Regimes

Catalyst Inlet Temperature Requirements

Catalyst Surface Requirements

Catalyst Lifetime

Catalytic Converter Design Options

Commercial Catalytic Converter

Technology

High-Temperature Catalyst

Low-Temperature Catalyst

Recommended Catalyst System Design

Cooling System Design Considerations

$\mathrm{CO}_{2}$ Removal System Design Considerations

Process Selection

Amine Solution Specifications

Absorption System Design

23

Gas Dryer Design Considerations

24

Process Selection

2.4

Drying System Design

DIESEL EXHAUST GAS PURIFICATION UNIT SYSTEM DESCRIPTION

System I - Desiccant Drying

System II - Refrigeration Cooling and Desiccant Drying 
TABLE OF CONTENTS (continued)

Section No.

Page No.

\section{3}

4

4.1

4.2

4.3

4.4

5
System III - High Pressure $\mathrm{CO}_{2}$ Removal and Desiccant Drying

SYSTEM ECONOMICS

Capital cost

Operating Costs

Maintenance Costs

Nitrogen Production Cost

REFERENCES

APPENDIX A

DISTRIBUTION
38

42

42

43

47

48

49

50

52 


\section{LIST OF ILLUSTRATIONS}

Figure

Page

1. Block process diagram of Purification Unit

2. Reaction rate versus temperature for fuel oxidation in the presence of a catalyst

3. Representation of breakpoint between kinetic and mass transfer control

4. Estimated catalyst durability (lifetime = t) as a function of surface temperature

5. Equilibrium lines for chemical and physical

6. Amine structural formulas

7. Dewpoints of aqueous triethylene glycol

8. Process flow diagram - System No. I

9. Trailer No. 1 - System No. I

10. Trailer No. 2 - System No. III

11. Trailer No. 3 - System No. I

12. Piping and instrumentation - System No. I

13. Process flow diagram - System No. II 35

14. Trailer No. I - System No. II 36

15. Trailer No. 2 - System No. II 37

16. Process flow diagram - System No. III 39

17. Trailer No. 1 - System No. III 40 


\section{LIST OF TABLES}

Table No.

1

2

3

4

5

6

7

Diesel engine characteristics

Page No.

Fabrication rates

7

42

System capital cost (single unit)

44

System capital cost (100 units)

46

Fuel consumption gal/hr

46

Yearly maintenance cost

47

Production cost, $\$ / 1000$ scf nitrogen

48 
EXECUTIVE SUMMARY

The high cost of drilling a geothermal well is one of the major factors affecting the economics of geothermal energy. Accelerated corrosion suffered by drill string components has been identified by Sandia National Laboratories as a significant contributor to these high drilling costs. A technique which minimizes this corrosion effect utilizes nitrogen as the drilling fluid. Unfortunately, liquid nitrogen delivered by oil field service companies is so expensive (\$9 to $\$ 17 / 1000$ scf depending on location) that even with the corrosion problem eliminated the overall drilling economics are adversely affected. This report describes the design of a transportable system that economically produces nitrogen suitable for use as a drilling fluid from the exhaust of a diesel engine.

The design specification, developed by Sandia Laboratories, called for a portable system that produced 1000 to $3000 \mathrm{scfm}$ of nitrogen which contains no more than: $50 \mathrm{ppm} \mathrm{O}_{2}, 50 \mathrm{ppm} \mathrm{NO}_{\mathrm{x}}$ $50 \mathrm{ppm} \mathrm{H}_{2} \mathrm{O}$, and 1 percent $\mathrm{CO}_{2}$.

During the course of the design program these specifications were modified as follows. Capacity was fixed at 2000 scfm as the size most compatible with typical air compressor diesel drive exhaust flow. $\mathrm{NO}_{\mathrm{X}}$ concentration was reduced to $2 \mathrm{ppm}$ to avoid warranty problems with the air compressors. $\mathrm{CO}_{2}$ concentration was set at less than 1 percent, this level being the lowest practically achievable concentration with a compact scrubbing system.

Additional specifications which impacted the design of the Purification Unit were the requirement to be self-supporting in electric power requirements and operate when water was not available. The system should also be able to operate in the temperature range $-50^{\circ} \mathrm{F}$ to $125^{\circ} \mathrm{F}$. The upper design temperature was later changed to $110^{\circ} \mathrm{F}$ to reflect the ASHRAE 2.5 percent summer design temperature in the regions where the unit was expected to be used, southern California and New Mexico.

The Diesel Exhaust Gas Purification Unit which resulted from this design contract is a trailer mounted, over-the-road transportable system which is capable of generating essentially (98+ percent) pure nitrogen from diesel engine exhaust. The major components of the system are:

a. A four-stage catalytic combustor/converter which will remove up to 12 percent oxygen from the exhaust and maintain $\mathrm{NO}_{x}$ and $\mathrm{O}_{2}$ levels below 2 ppm, and $50 \mathrm{ppm}$, respectively 
b. $\quad \mathrm{A} \mathrm{CO}_{2}$ scrubber system which utilizes aqueous monoethanolamine (MEA) to reduce the $\mathrm{CO}_{2}$ concentration in the exhaust to $<1$ percent

c. A desiccant dryer which dries the saturated nitrogen exiting the $\mathrm{CO}_{2}$ scrubber to a dew point of $-55^{\circ} \mathrm{F}$.

These components are mounted on two dropbed trailers and together with a trailer mounted $150 \mathrm{~kW}$ diesel generator, form a system which can be operated independently of any external power or water sypply.

The cost of producing 1000 scf of nitrogen with this system ranged from $\$ 1.34$ to $\$ 1.73$ depending on the type of diesel engine used in conjunction with the system and the total number of system purchased. The resulting cost of nitrogen to the drilling contractor are only about 25 percent of the cost of trucking liquid nitrogen to the site even allowing a 100 percent markup to the system operator. 


\section{INTRODUCTION}

Sandia National Laboratories, as program manager for the DOE/DGE Drilling and Completion Program, is evaluating projects showing a potential to effect a reduction in present geothermal well costs. One consideration which has merit for geothermal well cost reduction is the limiting of corrosion effects now experienced while drilling with aerated fluids. One method which will reduce this corrosion effect is the use of an inert, non-corrosive gas during drilling operations. Nitrogen $\left(\mathrm{N}_{2}\right)$ has been selected for use as the inert drilling fluid and, as such, must be capable of being produced in large, continuous quantities. This report describes the design and evaluates the economics of a system that will produce the specified quantity of nitrogen, at specified purity, from on-site-generated diesel exhaust.

The design specifications called for a portable system that produced 1000 to $3000 \mathrm{scfm}$ of nitrogen and shall contain no more than:

$$
\begin{array}{ll}
\text { a. } & \mathrm{O}_{2}-50 \mathrm{ppm} \\
\text { b. } & \mathrm{NO}_{\mathrm{x}}-50 \mathrm{ppm} \\
\text { c. } & \mathrm{H}_{2} \mathrm{O}-50 \mathrm{ppm} \\
\text { d. } & \mathrm{CO}_{2}-1 \text { percent }
\end{array}
$$

During the course of the design program these specifications were modified as follows. Capacity was fixed at $2000 \mathrm{scfm}$ as the size most compatible with typical air compressor diesel drive exhaust flow. $\mathrm{NO}_{\mathrm{X}}$ concentration was reduced to $2 \mathrm{ppm}$ to avoid warranty problems with the air compressors. $\mathrm{CO}_{2}$ concentration was set at less than 1 percent, this level being the lowest practically achievable concentration with a compact scrubbing system.

Additional specifications which impacted the design of the Purification Unit were the requirement to be self-supporting in electric power requirements and operate when water was not available. The system should also be able to operate in the temperature range $-50^{\circ} \mathrm{F}$ to $125^{\circ} \mathrm{F}$. The upper design temperature was later changed to $110^{\circ} \mathrm{F}$ to reflect the ASHRAE 2.5 percent summer design temperature in the regions where the unit was expected to be used, southern California and New Mexico. 
The Diesel Exhaust Gas Purification Unit which resulted from this design contract is a trailer mounted, over-the-road transportable system which is capable of generating essentially $\left(98^{+}\right.$percent) pure nitrogen from diesel engine exhaust. The major components of the system are:

a. A four-stage catalytic combustor/converter which will remove up to 12 percent oxygen from the exhaust and maintain NOX and $\mathrm{O}_{2}$ levels below $2 \mathrm{ppm}$, and $50 \mathrm{ppm}$, respectively

b. $\mathrm{A} \mathrm{CO}_{2}$ scrubber system which utilizes aqueous monoethanloamine (MEA) to reduce the $\mathrm{CO}_{2}$ concentration in the exhaust to $<1$ percent

c. A desiccant dryer which dries the saturated nitrogen exiting the $\mathrm{CO}_{2}$ scrubber to a dew point of $-55^{\circ} \mathrm{F}$.

The design considerations used to evaluate the recommended and alternate systems are presented in section 2 of this report. Section 3 presents detailed system descriptions of the recommended and alternate designs. The capital cost and overall economics of the various systems are presented in section 4.

This work was performed under Sandia Contract 61-1849. B.C. Casky of the Geothermal Technology Development Division was the technical contract monitor. 


\section{SYSTEM DESIGN CONSIDERATIONS}

\subsection{Basic Process}

A simplified block process diagram of a system which will meet the design and operating specifications discussed in Section 1 of this report is shown in Figure 1. Alternate techniques for performing each of the process steps are listed in that figure. In essence the diesel exhaust is directed to a catalytic burner where fuel is added, and the $\mathrm{O}_{2}$ and NOX levels are reduced to a specified limit of $50 \mathrm{ppm}$ and $2 \mathrm{ppm}$, respectively. The gas is then cooled and directed to the $\mathrm{CO}_{2}$ removal system where the $\mathrm{CO}_{2}$ concentration is reduced to less than 1 percent. The exhaust gas, now essentially wet $\mathrm{N}_{2}$, is then dried and sent to the compressor inlet. The alternative techniques for each of the process steps or subsystems are discussed in detail in the following subsections.

\subsection{Diese1 Engine Interface Requirements}

The diesel engine is not part of the Purification Unit, but since it is the source of the gas to be processed, its operating characteristics affect the design of the Purification Unit. A number of manufacturers supply engines of sizes appropriate to the geothermal drilling operation. Diesel engines in the size range of 600 to $1600 \mathrm{hp}$ are used to provide compression power and will generally supply the exhaust gas to the Purification Unit. Diesel engines operate under lean firing conditions, providing substantial gas volumes with oxygen levels between 6 to 12 percent depending on whether the engine is 4 or 2 cycle. The full power $\mathrm{O}_{2}$ level is usually not less than this to avoid making substantial levels of particulates, soot and smoke.

The variation of $\mathrm{O}_{2}$ level in the exhaust impacts the Purification Unit control system, and the relatively high level of O2 influences the catalytic burner design. The detrimental effect of increasing back pressure on diesel engine performance will influence component sizing (to minimize pressure drop) and may necessitate the use of a blower to supply the pressure head required to move the gas through the system.

oxygen levels and allowable back pressures of diesels currently used in air drilling applications are shown in Table 1.

\subsection{Catalyst System Design Considerations}

The discussion in the following subsections treats the parameters considered in the selection of the catalyst system for the Purification Unit. 
DIESEL EXHAUST PURIFICATION UNIT

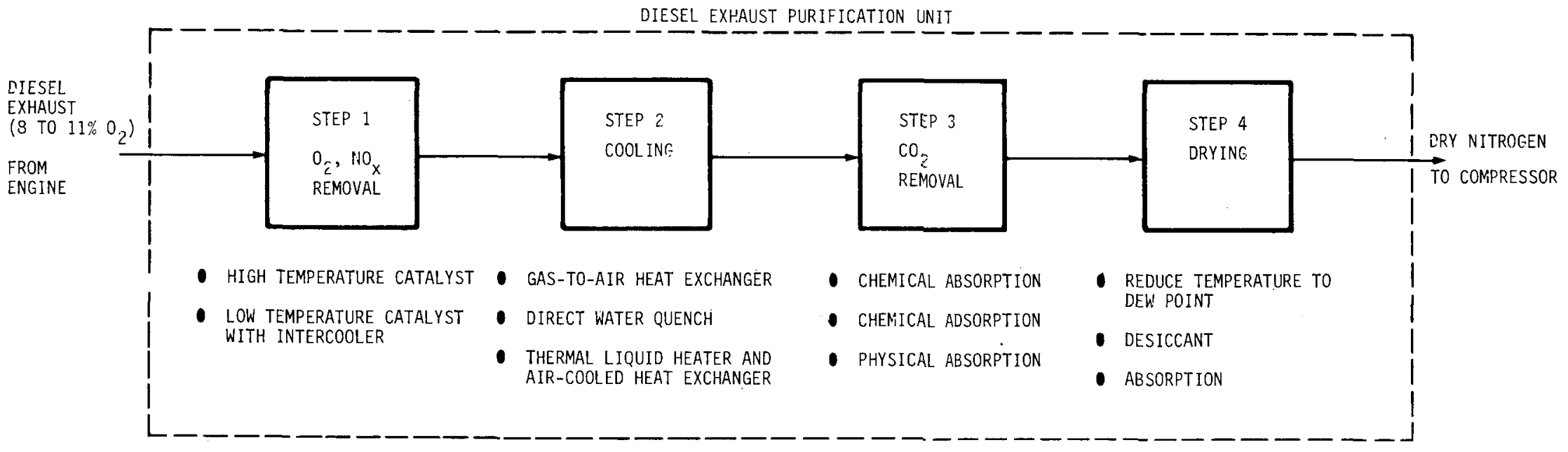

FIGURE 1. - Block process diagram of Purification Unit. 
TABLE 1. - Diesel engine characteristics

\begin{tabular}{|c|c|c|c|c|}
\hline \multirow{2}{*}{$\begin{array}{c}\text { Manufacturer } \\
\text { (model) }\end{array}$} & \multirow{2}{*}{$\begin{array}{l}\text { Power output } \\
\text { (horsepower) }\end{array}$} & \multicolumn{2}{|c|}{ Exhaust constituents } & \multirow{2}{*}{$\begin{array}{c}\text { Allowable } \\
\text { back pressure } \\
\left(\text { in. of } \mathrm{H}_{2} \mathrm{O}\right)\end{array}$} \\
\hline & & $\mathrm{O}_{2}$ (percent) & NO (ppm) & \\
\hline $\begin{array}{l}\text { Caterpillar } \\
398 \text { TA V12 } \\
\text { (4 cycle) }\end{array}$ & $\begin{array}{l}650 \\
450\end{array}$ & $\begin{array}{l}5.32 \\
7.00\end{array}$ & $\begin{array}{l}770 \\
800\end{array}$ & $<27$ \\
\hline $\begin{array}{l}\text { Waukesha } \\
2894 \\
(2 \text { cycle })\end{array}$ & $\begin{array}{l}585 \\
350\end{array}$ & $\begin{array}{l}10.0 \\
11.2\end{array}$ & - & $<14$ \\
\hline $\begin{array}{l}\text { GM } \\
7163-7000 \\
(2 \text { cycle })\end{array}$ & 532 & 12.0 & - & $<45$ \\
\hline
\end{tabular}

2.3.1 Catalyst Operating Regimes

The various regimes in which a catalyst can operate are illustrated in $\mathrm{F}$ igure 2. In Region $\mathrm{A}$, the rate of reaction is controlled by the total activity of the catalyst surface. This activity can be represented by a surface reaction rate constant $\mathrm{k}_{\mathrm{s}}$ where:

$$
k_{s} \propto N_{s} e^{-E_{a} / R T} s
$$

and,

$$
\begin{aligned}
& \mathrm{N}_{\mathrm{S}}=\text { number of catalytically active sites } \\
& \mathrm{E}_{\mathrm{a}}=\text { activation energy for the reaction of interest } \\
& \mathrm{T}_{\mathrm{S}}=\text { surface temperature } \\
& \mathrm{R}=\text { gas constant }
\end{aligned}
$$

Catalysts operating in this regime are said to be under kinetic control and behave as follows. 


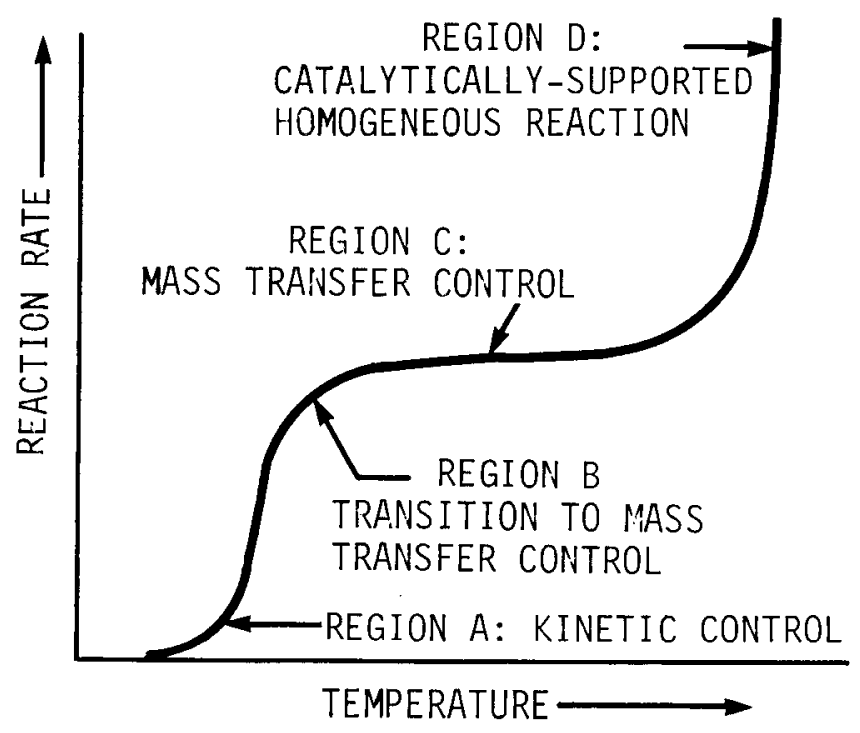

FIGURE 2. - Reaction rate versus temperature for fuel oxidation in the presence of a catalyst.

The surface temperature is initially the same as the bulk gas temperature. As the surface temperature rises to the ignition threshold, $T_{s}$ begins to increase rapidly and the surface concentration starts to fall. As the surface reaction rate accelerates, it approaches the rate at which reactant diffuses across the boundary layer on the catalyst surface. If there is sufficient temperature rise from the reaction, the surface reaction rate $k_{S}$ exceed the mass transfer rate $k_{g}$ and the reaction rate approaches the limiting rate termed the mass transfer limit. In this regime (Region $C$ ) the reaction rate is limited by the rate at which reactants can diffuse across the boundary layer. Under laminar flow conditions, the value of $\mathrm{kg}_{\mathrm{g}}$ is proportional to the laminar diffusion coefficient $D$, hence,

$$
\mathrm{k}_{\mathrm{g}} \alpha \mathrm{D} \quad \alpha \frac{\mathrm{T}_{\mathrm{b}}^{3 / 2}}{\mathrm{P}\left(\mathrm{V}_{\mathrm{A}}^{1 / 3}+\mathrm{V}_{\mathrm{B}}^{1 / 3}\right)^{2}} \sqrt{\frac{1}{\mathrm{M}_{\mathrm{A}}}+\frac{1}{\mathrm{M}_{\mathrm{B}}}}
$$


where:

$$
\begin{aligned}
\mathrm{T}_{\mathrm{b}} & =\text { bulk gas temperature } \\
\mathrm{P} & =\text { total pressure } \\
\mathrm{V}_{\mathrm{A}}, \mathrm{V}_{\mathrm{B}} & =\text { reactant molecular volumes } \\
\mathrm{M}_{\mathrm{A}}, \mathrm{M}_{\mathrm{B}} & =\text { reactant molecular weights }
\end{aligned}
$$

A catalyst system designed to operate under mass transfer control should have a significantly longer life and be easier to control than one which operates under kinetic control. This behavior follows from the fact that while under kinetic control any change in the number of active sites or in temperature will change the reaction rate. As the catalyst is used it will lose active sites. The loss can be either reversible, as in the case of poisoning with carbon deposits which can be washed off, or irreversible by sintering of the washcoat or poisoning with lead or phosphorous. In the case of mass transfer control this loss of active sites, unless catastrophic, will not affect the reaction rate since $\mathrm{k}_{\mathrm{s}}$ is much greater than required, in other words $\mathrm{k}_{\mathrm{s}}>\mathrm{k}_{\mathrm{g}}$.

If $\mathrm{T}_{\mathrm{b}}$ continues to increase the reaction moves to the homogeneous reaction regime. This regime is characterized by reactions which occur homogeneously throughout the gas phase and it is questionable what part the catalyst plays once the process is initiated. While operation in the homogeneous reaction regime is desirable from the point of view of minimizing the amount of catalyst required, it requires higher temperatures (greater than $18000 \mathrm{~F}$ ) than those at which catalysts have been successfully operated for extended periods.

Based on the previous discussion it is apparent that the catalyst system should be designed to operate in the mass transfer control region. The technique used to ensure operation in this region is explained in the following subsection.

\subsubsection{Catalyst Inlet Temperature Requirements}

The minimum inlet temperature at which mass transfer control is achieved for a given catalyst/reactant combination must be determined experimentally. It has proven convenient to plot in $(1-x)$, a measure of catalyst effectiveness, as a function of $1 / \mathrm{T}_{\mathrm{C}}$ where: 


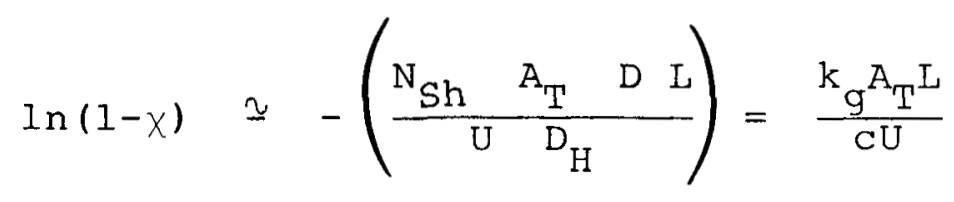

and,

$$
\begin{aligned}
& \mathrm{X}=\text { reactant conversion }=1-\frac{\text { Xout }}{\mathrm{Xin}} \\
& \mathrm{N}_{\mathrm{Sh}}=\text { Sherwood number } \\
& \mathrm{A}_{\mathrm{T}}=\text { geometrical bulk surface to volume ratio } \\
& \mathrm{D}=\text { diffusion coefficient } \\
& \mathrm{U}=\text { catalyst approach gas velocity } \\
& \mathrm{L}=\text { catalyst length } \\
& \mathrm{D}_{\mathrm{H}}=\text { honeycomb channel hydraulic diameter } \\
& \mathrm{k}_{\mathrm{G}}=\text { mass transfer coefficient } \\
& \mathrm{C}=\text { molar density } \\
& \mathrm{T}_{\mathrm{C}}=\text { catalyst inlet temperature }
\end{aligned}
$$

A plot of this nature is shown in Figure 3 . The breakpoint in the slope of the curve occurs at the transition from kinetic to mass transfer control. The temperature at which the break occurs is the minimum inlet temperature that will permit mass transfer control.

Once the minimum inlet temperature is determined, the magnitude of the allowable exotherm within the catalyst section can be determined. The allowable exotherm is equal to the maximum temperature consistent with the desired catalyst lifetime minus the required inlet temperature. The effect of temperature on catalyst lifetime is illustrated in Figure 4. The allowable exotherm will determine the amount of reactant that can be reacted within the catalyst. In this case the required inlet temperature is $\sim 650^{\circ} \mathrm{F}$, the maximum desired catalyst surface temperature is 


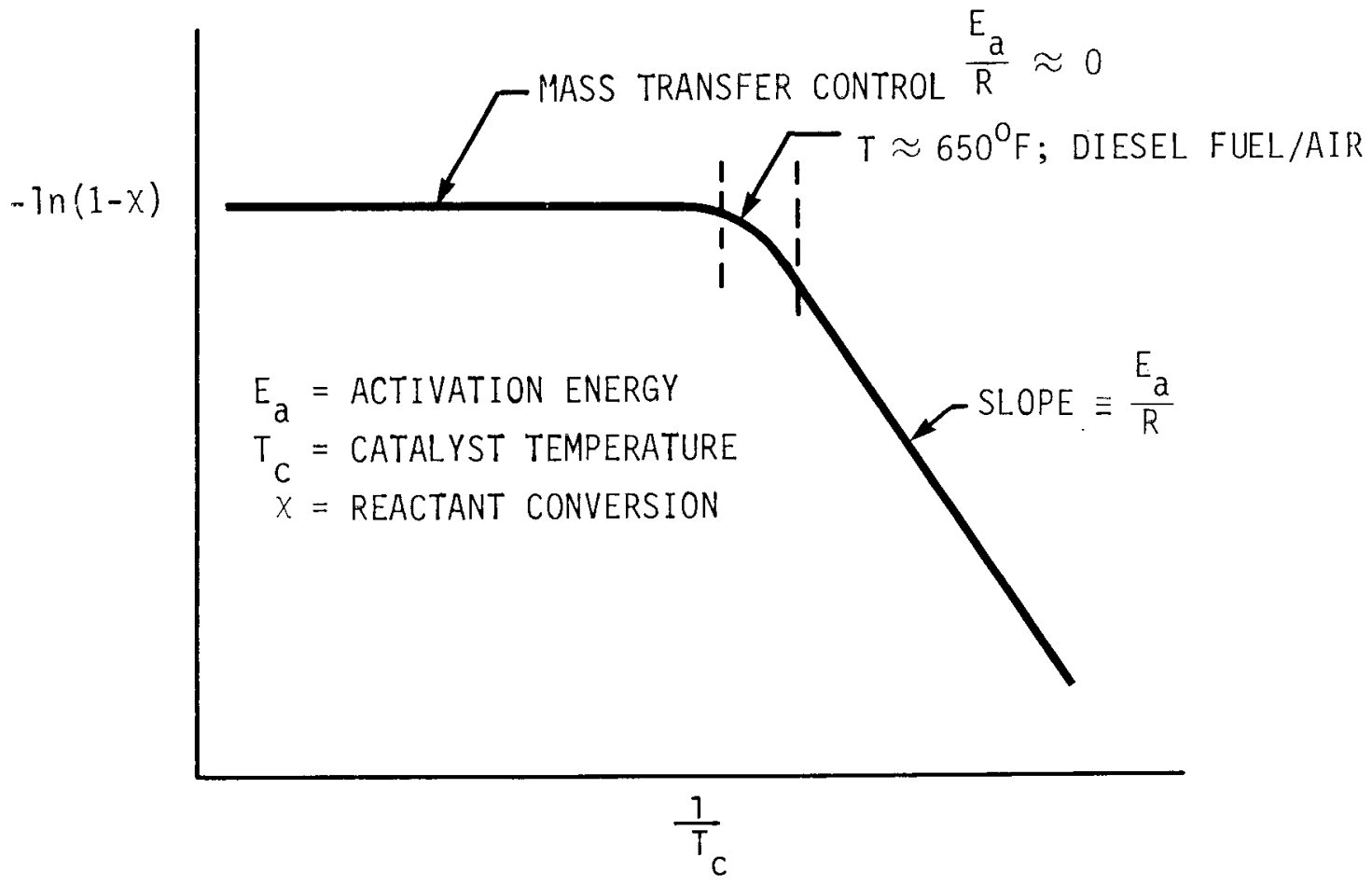

FIGURE 3. - Representation of breakpoint between kinetic and mass transfer control

$\sim 1400^{\circ} \mathrm{F}$, thus the allowable exotherm is $\sim 750^{\circ} \mathrm{F}$. Typical exotherms of $\sim 200^{\circ} \mathrm{F}$ are expected for each 1 percent $\mathrm{O}_{2}$ removed from the diesel exhaust, thus the design should limit $\mathrm{O}_{2}$ removal to 3 to 4 percent per stage in order to avoid rapid degradation of the catalyst performance.

\subsubsection{Catalyst Surface Requirements}

The total amount of catalyst required to achieve catalytic conversion objectives is obtained from an experimental data base which determines LMTU for various catalysts and reactants and from the integrated mass transfer control rate equation:

$$
-\ln (1-x) \simeq \frac{\mathrm{L}}{\mathrm{L}_{\mathrm{MTU}}}=\mathrm{N}_{\mathrm{MTU}}
$$




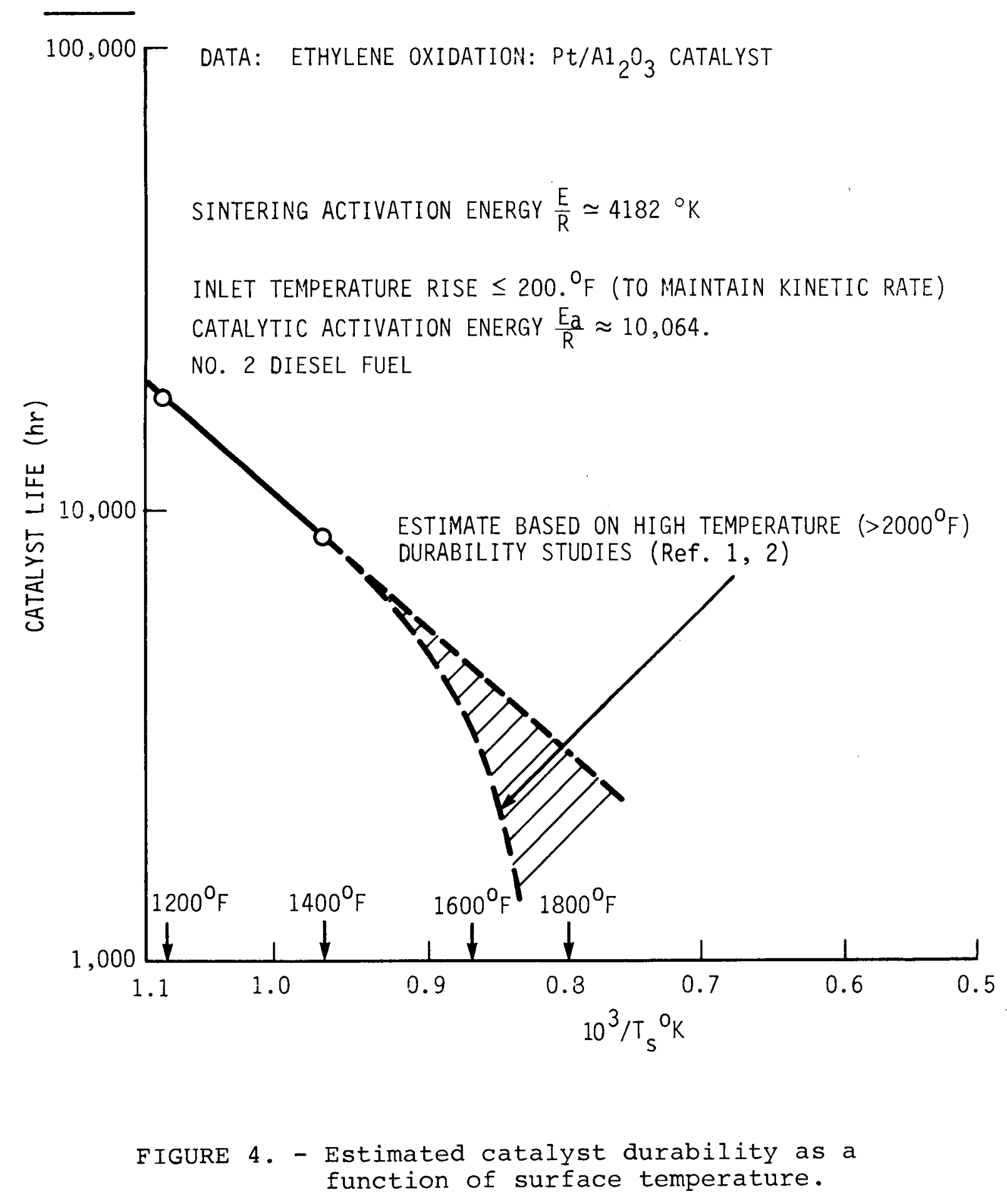


where:

$$
\begin{aligned}
& \mathrm{L}=\text { catalyst length } \\
& \mathrm{L}_{\mathrm{MTU}}=\text { length of a mass transfer unit } \\
& \mathrm{N}_{\mathrm{MTU}}=\text { number of mass transfer unit } \\
& \mathrm{L}_{\mathrm{MTU}}=\left[\begin{array}{lll}
\mathrm{N}_{\mathrm{Sh}} & \frac{\mathrm{A}_{\mathrm{T}}}{\mathrm{D}_{\mathrm{H}}} & \frac{\mathrm{D}}{\mathrm{U}}
\end{array}\right]^{-1}
\end{aligned}
$$

The design parameters are thus the geometrical arrangement and physical properties of the catalyst support since process conditions are fixed. In general adequate conversion cannot be obtained in a single segment catalyst length since boundary layer growth causes a rapid decrease in $\mathrm{k}_{\mathrm{g}}$ leading to inordinate length requirements. However, multiple segments in series can accomplish the desired conversion in an overall short converter length. It can be readily shown that:

$$
-\ln \frac{\left(1-x_{M S}\right)}{\left(1-x_{S S}\right)} \simeq N_{S}
$$

where:

$$
\begin{aligned}
& x_{M S} \quad \equiv \text { multi (series) segment catalyst conversion } \\
& x_{S S} \quad \equiv \text { single segment catalyst conversion } \\
& \mathrm{N}_{\mathrm{S}} \quad \equiv \text { number of segments } \\
& \text { Rearranging } x_{M S} \simeq 1-e^{-N_{S}}\left(1-x_{S S}\right)
\end{aligned}
$$

\subsubsection{Catalyst Lifetime}

Two processes which cause loss of activity are poisoning and sintering.

Sintering results in the irreversible loss of active sites. Sintering can involve loss of active sites by either direct modification of the catalyst by active site migration or damade to the high surface area washcoat which seals off active sites. 
The rate of sintering is generally an exponential function of temperature and can result in a catastrophic loss in activity at high temperatures. Thus, in a catalyst system designed to operate with the majority of the surface reaction under mass transfer control, catastrophic activity loss can result in the majority of the surface reverting to kinetic control and an inability to meet reaction conversion requirements. It is this behavior which results in the dramatic decrease in catalyst lifetime with increasing temperature illustrated in Figure 4.

While sintering losses are always irreversible, losses of active sites via poisoning may be reversible or irreversible. Reversible losses occur when deposits of materials on active sites prevent access of reactants to them. Certain materials, such as sulfur compounds, can be removed by washing with a suitable solvent while others, such as carbon deposits, can be burned off.

Irreversible losses occur when compounds of lead, phosphorous and arsenic combine with the active site permanently. In practice, a combination of sintering and poisoning occurs, gradually leading to a significant deterioration in performance. Loss of activity can be compensated for by increases in bulk gas inlet temperature. Naturally this exacerbates the sintering rate; however, substantial increases in kinetic rate are obtainable for just a few degrees rise in inlet temperature.

\subsection{Catalytic Converter Design Options}

\subsubsection{Commercial Catalytic Converter Technology}

The processes which have been commercially proven are based on technology developed for the automotive catalytic muffler. NOX, CO and unburned hydrocarbons are readily removed using special catalysts developed for this purpose. This standard technology is a low-temperature technology (12000F to $16000 \mathrm{~F})$, although the temperatures are still very severe for the ceramic materials used in active catalyst preparation. These catalysts carry out their $\mathrm{NOX}$ function in a reducing atmosphere, requiring fuel-rich operation of the engine, and resulting in high CO emissions (a toxic gas). To achieve low CO emissions, either a second converter stage is used or very close control of stoichiometry with single-stage converters is required.

For oilfield use, oxygen-depleted inert gas has been generated by adding special catalytic converters downstream of internal combustion engines using gasoline or sweet natural gas fuels. The low oxygen level in the exhaust of these engines permits low temperature catalyst technology to be used. 
The diesel engine has not previously been used for inert gas generation since the high levels of $\mathrm{O}_{2}$ present in the exhaust present problems for existing catalyst systems. There are, however, several catalytic converters being developed which are compatible with diesel engine exhaust gas. The companies pursuing this development include:
a. Engelhard Minerals and Chemicals Corp.
b. Universal Oil Products
c. Johnson Matthey Co.
d. Metpro (formerly OXY-Catalyst Co.)

The new converter designs allow up to 8 to 9 percent $\mathrm{O}_{2}$ to be reacted with additional fuel, using a catalyst formulated for high temperature service (up to $2400^{\circ} \mathrm{F}$ ). Design methods for these catalysts have been developed and excellent empirical correlations have been obtained for a range of fuels and potential applications.

A diesel exhaust converter of this type, evaluated under contract to Sandia (2), demonstrated that fuel could be injected and mixed with diesel exhaust and combusted simultaneously to deplete $\mathrm{O} 2$ and $\mathrm{NOX}$. The fuel-rich operation required to achieve low $\mathrm{O}_{2}$ and $\mathrm{NOX}$ emissions resulted in high levels of CO (up to 10 percent under manual controll. Lowest levels of co were achieved by near-stoichiometric operation of the converter; however, this was only possible at the highest load condition where the diesel exhaust $\mathrm{O}_{2}$ level. was less than 8 percent. This limitation is imposed to prevent the catalyst temperature from rising above $24000 \mathrm{~F}$. This temperature constraint must be observed to maintain adequate catalyst activity $(\underline{3}, \underline{4})$.

The design options available for the catalytic converter fall into two general categories: high temperature catalysis and low temperature catalysis. These options are described below :

\subsubsection{High-Temperature Catalysis}

The catalyst for this process is typically a precious metal (platinum, palladium) on a high surface area washcoat $\left(\gamma-\mathrm{Al}_{2} \mathrm{O}_{3}\right)$ stabilized with proprietary additives of the rare earth type and deposited on a ceramic monolith which is capable of withstanding temperatures in the range of 26000 to $3000{ }^{\circ} \mathrm{F}$. Typically, the catalyst requires an in let temperature in the range 6800 to $8000 \mathrm{~F}$. O2 levels less than 9 percent are necessary to limit exhaust temperatures to less than $2400^{\circ} \mathrm{F}$.

This converter must be operated fuel-rich to achieve simultaneous $\mathrm{O}_{2}$ and $\mathrm{NOX}$ removal. Flexibility in accepting variable inlet $\mathrm{O}_{2}$ levels could be provided with fuel-rich operation; however, CO emissions would be in the several percent range. 
Since this is a toxic insoluble gas, it would be released to the atmosphere in the vicinity of the drilling operation and could pose significant health hazards. An alternative approach would be to dilute the diesel exhaust with cooled catalyst exhaust. This technique would allow a much closer approach to stoichiometric catalyst operation and thus reduce otherwise high CO emissions.

As discussed above, single-stage converters of this type for use with diesel engine exhaust are relatively new and unproven in long term field operation. In addition, design complexities (exhaust gas recycling or cooling) are introduced when $\mathrm{O}_{2}$ levels exceed 9 percent as is the case for use with a 2-cycle diesel engine. In the new converter system which was demonstrated under contract to Sandia, both $\mathrm{O}_{2}$ and $\mathrm{NO}_{\mathrm{X}}$ reduction were demonstrated under rich firing conditions with Co emissions up to several percent. $\mathrm{O}_{2}$ removal was limited to approximately 8 to 9 percent. Catalyst operation was limited by the maximum temperature of $\approx 2350^{\circ} \mathrm{F}$, with little margin either way to maintain catalyst performance. Test duration was $<200 \mathrm{hr}$ cumulative (3). Although several investigations have been carried out with this new converter, it is essentially unproven technology for the 6,000 to 7,000 hr required for a commercial system. In addition, there is no commercial supplier of high temperature catalyst supports of the honeycomb type essential for low pressure losses and none of the catalyst suppliers contacted during the course of this contract were willing to supply a catalyst system of this type on a commercial basis.

\subsubsection{Low-Temperature Catalysis}

In this process the preferred catalyst and washcoat system would be similar to the high-temperature system, but a wider range of catalyst supports (monoliths, pellets, etc.) could be used, due to the lower temperature. Commercially available catalytic converters of this type can be significantly less costly, and are inherently more durable due to lower temperature operation $\left(\leq 1200^{\circ}\right.$ to $\left.1400^{\circ} \mathrm{F}\right)$.

This low temperature limit restricts the maximum $\mathrm{O}_{2}$ removal capability of a single converter to the range of 3 to 4 percent (see subsection 2.3.2). Therefore, the converter design must be multistage and incorporate interstage cooling. Such active cooling will permit the converter to operate over a wide range of exhaust $\mathrm{O}_{2}$ concentrations. Thus, fuel rich operation of the first stage is not required to limit catalyst temperature rise, and there is no significant. CO and soot production. The last stage converter would be operated near stoichiometric conditions and may be designed for optimal $\mathrm{CO}$ and $\mathrm{NO}_{\mathrm{x}}$ reduction at a much lower operating temperature. 
Although the interstage cooler makes the design more complex, it permits the use of low temperature catalytic converters which are more reliable than their high temperature counterparts. In addition, even the high-temperature converter would need cooling (or some other design complexity) to handle the variable exhaust $\mathrm{O}_{2}$ levels over the full range of diesel engine power settings. Thus, considering the state of the art, low-temperature catalysis was selected for this application.

\subsection{Recommended Catalyst System Design}

A multistage low temperature catalysis system has been selected for the recommended Purification unit design. The fourstage catalytic combustor/converter will remove up to 12 percent oxygen from the diesel exhaust and maintain $\mathrm{NO}_{\mathrm{X}}$ and $\mathrm{O}_{2}$ levels below $2 \mathrm{ppm}$ and $50 \mathrm{ppm}$, respectively. The four-stage system is recommended based on a lifetime versus cost optimization considering catalyst durability and capital and maintenance costs. Under continuous operation with 11 percent oxygen in the diesel exhaust (typical of 2-cycle engines) the catalyst will have a lifetime of approximately $6000 \mathrm{hr}$. With a 6.5-percent oxygen concentration (typical of 4-cycle engines), the catalyst lifetime will be approximately $17,000 \mathrm{hr}$.

The exhaust from the diesel engine is ducted to the inlet of the first-stage catalytic combustor. A preheater is used to maintain the exhaust temperature at the $650^{\circ} \mathrm{F}$ required to ensure the desired reaction rate in the catalyst bed. The oxygen level of the exhaust gas is measured at this point and used to generate a set point for the fuel system. The set point is 62.5 percent of the measured $\mathrm{O}_{2}$ level; the controlled process variable is the $\mathrm{O}_{2}$ concentration at the outlet of the firststage catalytic combustor. The fuel flow is distributed such that the oxygen is removed in the following manner:

$\begin{array}{cl}\frac{\circ}{\mathrm{O}_{2} \text { removed }} & \text { Catalyst } \\ 37.5 & \text { lst stage } \\ 29.2 & \text { 2nd stage } \\ 29.2 & \text { 3rd stage } \\ \frac{4.1}{100.0} & 4 \text { th stage }\end{array}$

With the exception of the fourth stage all stages run lean. The fourth stage is run slightly rich to permit $\mathrm{NO}_{\mathrm{X}}$ removal.

Therminol heat exchangers between each catalyst bed act as intercoolers to control the inlet temperature to the next catalyst stage, thus controlling activity and maximum temperature in the catalyst bed. The set point of the inlet temperature 
control can be increased as the catalyst ages in order to maintain the required catalyst activity.

The combined pressure drop of the catalytic combustors/ converters and the intercoolers/aftercoolers is approximately $20 \mathrm{in}$. of water. The total system back pressure on the diesel would be about 25 in. at design flow. This back pressure will permit operation with all diesel engines of interest except the 2-cycle Waukesha. The low, 14 in. water, allowable back pressure for this engine makes it unlikely that a reasonably sized purification system could be coupled to it.

\subsection{Cooling System Design Considerations}

The heat load which the system must reject is the sensible heat of the combustion products (4 MBtu/hr/1000 scfm $\mathrm{N}_{2}$ ). The process gas temperature must be dropped to approximately $120^{\circ} \mathrm{F}$ to be compatible with air compressor inlet requirements. The fact that this must be done without cooling water requires that an air-cooled heat exchanger be used as the ultimate heat sink for the system.

The air-cooled heat exchangers used for the system heat sink are of the liquid to air finned tube type. Three separate heat exchangers are required to cool the lean amine solution, control the temperature of the Therminol delivered to the reboiler, and condense steam from the regenerator. In order to minimize the space occupied by these heat exchangers, the finned tube bundle is arranged vertically to form the sides of a box. An induction fan is used to draw air over the tube bundle. The dimensions of the box were selected to permit use of the largest diameter fan possible, limited by 8-ft width of the trailer. Maximizing the fan diameter minimizes the fan power requirements. An ambient design temperature of ll0OF, corresponding to the ASHRAE 5-percent summer time design temperature for Blythe, CA, was used to determine the heat transfer surface requirements.

The catalyst system intercoolers must control the inlet temperature to the following catalyst stage. These heat exchangers should be compact to facilitate system arrangement and have a low process side pressure drop so as not to adversely affect the diesel engine. These requirements coupled with the desire to use this waste heat for amine and desiccant regeneration make a thermal fluid heat transfer loop the most practical approach toward intercooling. A heat transfer fluid, Therminol, will be used. The intercoolers can be of carbon steel construction with bare tube design to minimize gas side pressure drop. In order to achieve the lowest $\mathrm{CO}_{2}$ scrubber inlet temperature possible, a process gas to air heat exchanger will 
Although the interstage cooler makes the design more complex, it permits the use of low temperature catalytic converters which are more reliable than their high temperature counterparts. In addition, even the high-temperature converter would need cooling (or some other design complexity) to handle the variable exhaust $\mathrm{O}_{2}$ levels over the full range of diesel engine power settings. Thus, considering the state of the art, low-temperature catalysis was selected for this application.

\subsection{Recommended Catalyst System Design}

A multistage low temperature catalysis system has been selected for the recommended Purification Unit design. The fourstage catalytic combustor/converter will remove up to 12 percent oxygen from the diesel exhaust and maintain $\mathrm{NO}_{X}$ and $\mathrm{O}_{2}$ levels below $2 \mathrm{ppm}$ and $50 \mathrm{ppm}$, respectively. The four-stage system is recommended based on a lifetime versus cost optimization considering catalyst durability and capital and maintenance costs. Under continuous operation with 11 percent oxygen in the diesel exhaust (typical of 2-cycle engines) the catalyst will have a lifetime of approximately $6000 \mathrm{hr}$. With a 6.5-percent oxygen concentration (typical of 4-cycle engines), the catalyst lifetime will be approximately $17,000 \mathrm{hr}$.

The exhaust from the diesel engine is ducted to the inlet of the first-stage catalytic combustor. A preheater is used to maintain the exhaust temperature at the $650^{\circ} \mathrm{F}$ required to ensure the desired reaction rate in the catalyst bed. The oxygen level of the exhaust gas is measured at this point and used to generate a set point for the fuel system. The set point is 62.5 percent of the measured $\mathrm{O}_{2}$ level; the controlled process variable is the $\mathrm{O}_{2}$ concentration at the outlet of the firststage catalytic combustor. The fuel flow is distributed such that the oxygen is removed in the following manner:

\begin{tabular}{cl}
$\frac{\mathrm{o}_{2} \text { removed }}{37.5}$ & Catalyst \\
\hline 29.2 & lst stage \\
29.2 & 2nd stage \\
$\frac{4.1}{100.0}$ & 3rd stage \\
\hline & 4th stage
\end{tabular}

With the exception of the fourth stage all stages run lean. The fourth stage is run slightly rich to permit $\mathrm{NO}_{X}$ removal.

Therminol heat exchangers between each catalyst bed act as intercoolers to control the inlet temperature to the next catalyst stage, thus controlling activity and maximum temperature in the catalyst bed. The set point of the inlet temperature 
control can be increased as the catalyst ages in order to maintain the required catalyst activity.

The combined pressure drop of the catalytic combustors/ converters and the intercoolers/aftercoolers is approximately 20 in. of water. The total system back pressure on the diesel would be about 25 in. at design flow. This back pressure will permit operation with all diesel engines of interest except the 2-cycle Waukesha. The low, 14 in. water, allowable back pressure for this engine makes it unlikely that a reasonably sized purification system could be coupled to it.

\subsection{Cooling System Design Considerations}

The heat load which the system must reject is the sensible heat of the combustion products (4 MBtu/hr/1000 scfm $\mathrm{N}_{2}$ ). The process gas temperature must be dropped to approximately $120^{\circ} \mathrm{F}$ to be compatible with air compressor inlet requirements. The fact that this must be done without cooling water requires that an air-cooled heat exchanger be used as the ultimate heat sink for the system.

The air-cooled heat exchangers used for the system heat sink are of the liquid to air finned tube type. Three separate heat exchangers are required to cool the lean amine solution, control the temperature of the Therminol delivered to the reboiler, and condense steam from the regenerator. In order to minimize the space occupied by these heat exchangers, the finned tube bundle is arranged vertically to form the sides of a box. An induction fan is used to draw air over the tube bundle. The dimensions of the box were selected to permit use of the largest diameter fan possible, limited by 8-ft width of the trailer. Maximizing the fan diameter minimizes the fan power requirements. An ambient design temperature of ll00F, corresponding to the ASHRAE 5-percent summer time design temperature for Blythe, CA, was used to determine the heat transfer surface requirements.

The catalyst system intercoolers must control the inlet temperature to the following catalyst stage. These heat exchangers should be compact to facilitate system arrangement and have a low process side pressure drop so as not to adversely affect the diesel engine. These requirements coupled with the desire to use this waste heat for amine and desiccant regeneration make a thermal fluid heat transfer loop the most practical approach toward intercooling. A heat transfer fluid, Therminol, will be used. The intercoolers can be of carbon steel construction with bare tube design to minimize gas side pressure drop. In order to achieve the lowest $\mathrm{CO}_{2}$ scrubber inlet temperature possible, a process gas to air heat exchanger will 
be used in the final cooling step of the process gas flow. This heat exchanger will be a $\mathrm{z}$-duct counterflow unit and should be fabricated from stainless steel since it will be subjected to acid condensation when operating at ambient temperatures below $110^{\circ} \mathrm{F}$. Use of direct water quench cooling for this last step would be more efficient and less expensive, but the absence of a cooling water source precluded the use of this approach.

$2.7 \mathrm{CO}_{2}$ Removal System Design Considerations

The discussion in the following subsections treats the parameters considered in the design of the $\mathrm{CO}_{2}$ removal system for the Purification Unit.

\subsubsection{Process Selection}

There are a number of commercially-proven processes which could be used to reduce the $\mathrm{CO}_{2}$ level in the exhaust gas to the less than 1 percent. All of the viable processes are absorptive in nature. Adsorption processes, such as molecular sieves or activated carbon, are not effective because the $\mathrm{CO}_{2}$ partial pressure in the Purification Unit is too low. Even if $\mathrm{CO}_{2} \mathrm{re}-$ moval was carried out downstream of the primary compressor where the gas pressure is highest ( 300 psig) the $\mathrm{CO}_{2}$ partial pressure is still too low for an adsorption process to be effective.

Absorption processes, both physical and chemical, have proven successful for the purification of industrial raw gases, mainly for the removal of acidic components or production of industrial gases $\left(\mathrm{CO}_{2}\right.$ and/or $\mathrm{H}_{2} \mathrm{~S}$ for sulfur recovery). In selecting the most appropriate process, attention must be given to the gaseous components to be removed, their partial pressures, the thermal loads (heats of absorption and process gas temperature) and physical constraints (absorption column size).

The general applicability of chemical and physical absorption processes can be seen from the two typical equilibrium curves presented in Figure 5. According to the curves, physical absorption is preferable when the component to be removed has a high partial pressure while chemical absorption should be chosen when the partial pressure is low.

With low partial pressure of the component to be removed, for example, $\mathrm{p}_{2}$ in Figure 6 , the chemical solvent can absorb a much higher load, which decreases the solvent circulation rate, whereas with high partial pressure, for example, p1, the physical solvent is more advantageous. While chemical absorption is 


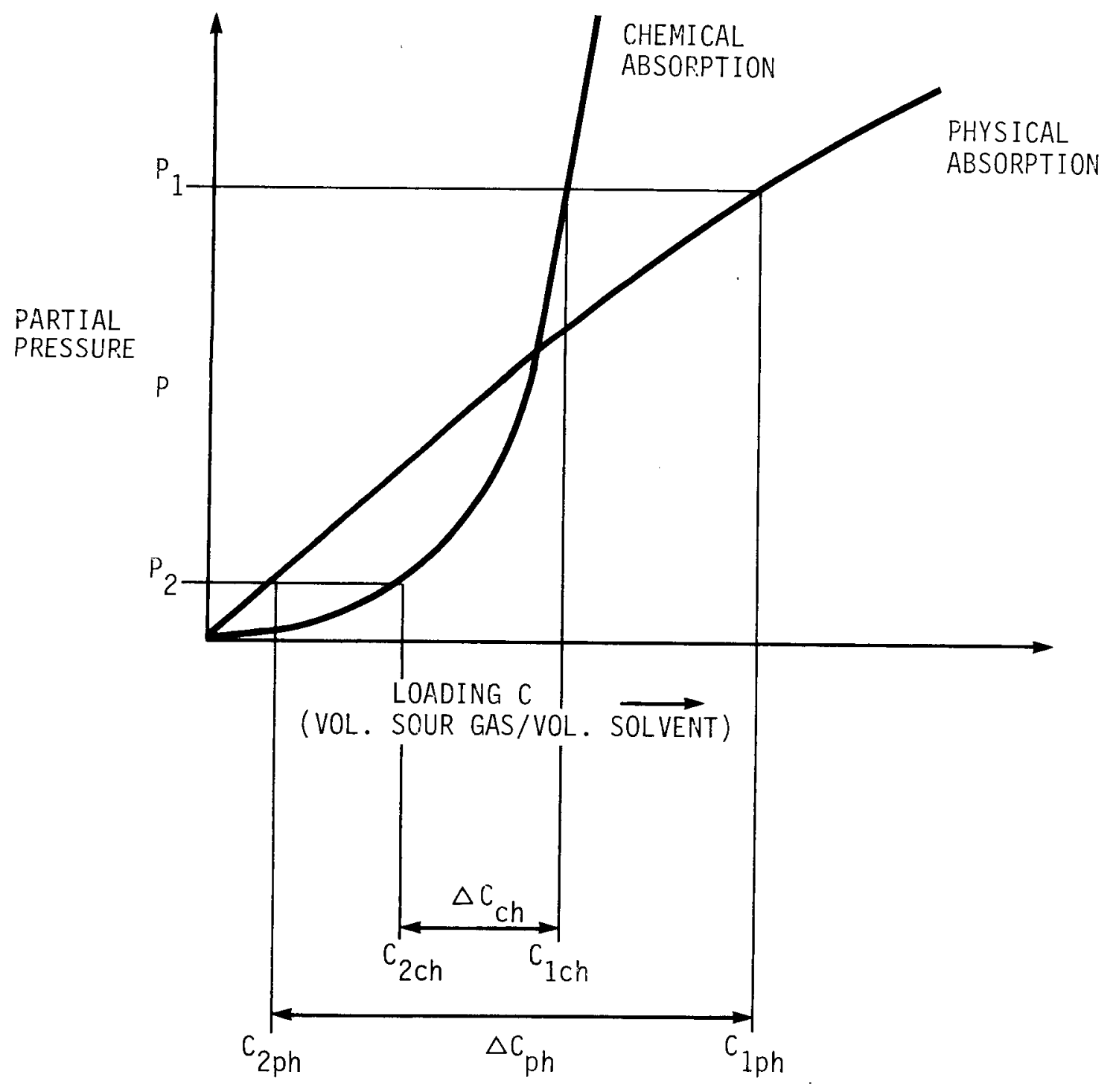

FIGURE 5. - Equilibrium lines for chemical and physical absorption.

20 
characterized by a saturation phenomenon above a certain partial pressure, loading in physical absorption increases almost proportional to the partial pressure (Henry's law). Therefore, the solvent circulation rate required for physical absorption is substantially independent on the content of the sour component in the crude gas but is merely proportional to the crude gas quantity. The higher the operating pressure the lower the circulating solvent rate.

Physical absorption processes such as Rectisol ${ }^{\circledR}, \operatorname{Purisol}^{\circledR}$, and Selexol ${ }^{\circledR}$ are proven commercial methods for removal of $\mathrm{CO}_{2}$, $\mathrm{H}_{2} \mathrm{~S}$, COS (carbon oxysulfide) and $\mathrm{H}_{2} \mathrm{O}$ provided the partial pressure of the species is on the order of 50 lb/in.2. In this application, this would necessitate placing the $\mathrm{CO}_{2}$ removal unit downstream of the compressor, thus making these processes unattractive.

At the lower system pressures upstream of the compressor, chemical absorption processes such as the amine chemical solvent process can be used. $\mathrm{CO}_{2}$ and $\mathrm{H}_{2} \mathrm{~S}$ have a high solubility in amine, and substantial heat of reaction is produced. The $\mathrm{CO}_{2}$ saturated amine solution can be regenerated by heating, thus providing a significant heat sink for the sensible heat of the catalytic converter exhaust and minimizing chemical makeup requirements.

Other chemical absorption processes such as the Eichmeyer CATACARB ${ }^{\circledR}$ process which use catalyzed hot potassium carbonate are not very effective at $\mathrm{CO}_{2}$ partial pressures below 35 psig. Thus, they are not attractive for this application, leaving the amine process as the only viable $\mathrm{CO}_{2}$ removal approach for use with the Purification Unit.

\subsubsection{Amine Solution Specifications}

The two amines which have proved to be of commercial interest for gas purification are monoethanolamine (MEA) and diethanolamine (DEA). Structural formulas for these amines are presented in Figure 6.<smiles>CC(C)(N)C(C)(C)O</smiles>

MONOETHANOLAMINE<smiles>CC1(C)C(O)(O)C2(C)NNC12C</smiles>

DIETHANOLAMINE

FIGURE 6. - Amine structural formulas. 
In general, it can be considered that the hydroxyl group serves to reduce the vapor pressure and increase the water solubility, while the amine group provides the necessary alkalinity in water solutions to cause absorption of acidic gases.

The principle reactions occurring when an alkanolamine is used to absorb $\mathrm{CO}_{2}$ may be represented as follows:

$$
\begin{aligned}
& 2 \mathrm{RNH}_{2}+\mathrm{CO}_{2}+\mathrm{H}_{2} \mathrm{O} \rightleftarrows\left(\mathrm{RNH}_{3}\right)_{2} \mathrm{CO}_{3} \\
& \left(\mathrm{RNH}_{3}\right)_{2} \mathrm{CO}_{3}+\mathrm{CO}_{2}+\mathrm{H}_{2} \mathrm{O} \rightleftarrows 2 \mathrm{RNH}_{3} \mathrm{HCO}_{3} \\
& 2 \mathrm{RNH}_{2}+\mathrm{CO}_{2} \rightleftarrows \mathrm{RNH} \mathrm{COONH}_{3} \mathrm{R}
\end{aligned}
$$

These products have appreciable vapor pressures under normal conditions so that the composition of the equilibrium solution varies with the partial pressure of the acidic gases over it. The absorbed gases can be easily stripped from the solution by the application of heat because of the rapid increase in vapor pressure with temperature.

The most rapid and direct reactions with $\mathrm{CO}_{2}$ occur with monoethanolamine and diethanolamine reaction (3). Tertiary amines, such as triethanolamine and methyldiethylanolamine absorb $\mathrm{CO}_{2}$ more slowly in accordance with reaction (1) and (2). Monoethanolamine is the preferred solvent when the gas is at low pressure and maximum removal of $\mathrm{CO}_{2}$ is required. The low molecular weight of monoethanolamine results in a high solution capacity at moderate concentrations (on a weight basis). It also has a high alkalinity and can be reclaimed relatively easily from contaminated solutions.

A potential disadvantage of the MEA process is that MEA reacts with carbon oxysulfide (COS) to form a nonregenerable compound. The level of $\mathrm{COS}$ in the converter exhaust will depend on the sulfur content of the fuel, the catalyst selected and stoichiometry at the operating point. If significant levels of COS are present, the MEA could be replaced with diethanolamine (DEA) but an economic penalty will be incurred. With the relatively low level of sulfur $(\sim 0.2$ percent) expected in the diesel fuel and the complete stoichiometric combustion expected with the catalyst system, $\cos$ is not expected to be a problem and MEA will be the specified amine. 
In the typical absorber unit the gas to be treated passes upward through the absorber column, countercurrent to a stream of $\mathrm{CO}_{2}$-lean, MEA solution. The $\mathrm{CO}_{2}$ from the gas is absorbed by the liquid, in accordance with reaction (3) which then exits as a $\mathrm{CO}_{2}$-rich solution at the bottom of the column. The rich solution is heated by heat exchange with the lean solution and then fed to the top of the regenerator. Heat applied to the regenerator strips the $\mathrm{CO}_{2}$ from the MEA solution in accordance with the reverse of reaction (3). The rate at which the amine solution is circulated depends on the amine solution concentration and the allowable acid gas pickup (moles of $\mathrm{CO}_{2} /$ mole of $\mathrm{MEA}$ ). A MEA concentration of 15 percent by weight is generally the maximum concentration that can be used without causing severe corrosion. Higher concentrations can be used when a corrosion inhibitor is employed. The purpose of using a higher concentration is to reduce the energy costs associated with regenerating the $\mathrm{CO}_{2}$-rich amine solution. In our case this is not a primary concern since we are utilizing waste heat from the catalyst system intercoolers to regenerate the MEA. Thus, a 15-percent MEA solution has been selected for the design.

Based on a 15-percent MEA solution and an acid gas pickup of 0.36 moles of $\mathrm{CO}_{2}$ per mole of MEA, a MEA circulation rate of $140 \mathrm{gal} / \mathrm{min}$ is required for the design flow of $2000 \mathrm{scfm}$ of inert gas.

\subsubsection{Absorption System Design}

The absorber and regenerator columns can be of either the tray or packed type. Packed columns are generally used when a high degree of $\mathrm{CO}_{2}$ removal is required. The higher efficiencies obtained with packed columns result in a shorter column. This latter point is very important in this application because roadability constraints limit the overall height of the unit to 13 ft 6 in. (including the trailer).

Standard mass transfer calculations using empirically determined mass transfer coefficients presented in Kohl and Riesenfeld ( 4 ) were used to size the absorber column. Generally speaking, the tower diameter and height are functions of the liquid and gas flow rates and the type of packing. For a column packed with raschig rings, the specified gas and liquid rates require a $5 \mathrm{ft}$ diam column, with a packed height of $10 \mathrm{ft}$. The regenerator would be approximately the same size. Because of the limited headroom available on a trailer, this necessitates a series arrangement of at least two absorber columns and two regenerator columns. This requires having two sets of tanks, internals, controls, piping, etc., for both the absorber and the regenerator. It also requires a sizeable amount of space. 
The preferred design utilizes a high efficiency packing, such as koch sulzer packing, rather than a standard dumped packing, such as raschig rings, and permits a reduction in space required for the $\mathrm{CO}_{2}$ removal unit. With the high efficiency packings only one absorber and one regenerator are required. Adequate $\mathrm{CO}_{2}$ removal can be accomplished in a $6 \mathrm{ft} 6$ in. diam absorber with a packed height of $3 \mathrm{ft}-4 \mathrm{in}$. The regenerator would be the same size. These sizes are based on atmosphere pressure and a gas inlet temperature of $130^{\circ} \mathrm{F}$. Increasing the pressure or reducing the temperature will enhance the acid gas pickup rate and increase the efficiency of the column.

\subsection{Gas Dryer Design Considerations}

The discussion in the following subsections treats the parameters considered in the design of the gas drying system for the Purification Unit.

\subsubsection{Process Selection}

At the design condition, the process gas stream will exit the $\mathrm{CO}_{2}$ scrubber at $130^{\circ} \mathrm{F}$, saturated with water and at essentialli atmospheric pressure. Meeting the $50 \mathrm{Vppm} \mathrm{H}_{2} \mathrm{O}$ specification under these conditions is a difficult drying job, which is further complicated by the lack of cooling water and a high ambient (1100F) design temperature.

Gas drying at low pressures is typically accomplished with refrigeration type dryers. In order to meet the low moisture specification the process gas stream would have to be cooled to approximately $-550 \mathrm{~F}$. This approach is clearly not practical, however, a system employing a refrigeration dryer to remove the bulk of the moisture, $60^{\circ} \mathrm{F}$ dewpoint, followed by a desiccant to perform the final drying would be practical in most cases. However, in this case, the lack of a cooling water supply dramatically increases the cost of the refrigeration unit. This cost increase coupled with the increased auxiliary power load make this approach economically unattractive.

An alternative to refrigeration drying is to use an absorption type dryer employing a hydroscopic liquid such as triethylene glycol. The amount of water removed is simply a function of the temperature and concentration of the solution in the spray unit. A means of removing heat of solution and condensation must also be supplied. Using the heat available with indirect heat exchange of combustion gas heat for regeneration could make the operating costs of a chemical absorption unit attractive. 
Minimum equilibrium dewpoints attainable with various triethylene glycol- $\mathrm{H}_{2} \mathrm{O}$ solutions are shown in Figure 7 . Practical dewpoints are typically 200 to $30^{\circ} \mathrm{F}$ higher and since we would be in the $120^{\circ}$ to $130^{\circ} \mathrm{F}$ contact temperature range, little dewpoint reduction could be achieved with practical glycol concentrations.

The remaining drying process accomplishes all the moisture removal using a desiccant. This process is generally only used at high pressures where the moisture content of the gas has already been lowered during the compression process. The major drawback to using the desiccant for removing high moisture loads from a gas stream is that a practically sized desiccant bed would have to be regenerated frequently with each regeneration cycle consuming a large quantity of power. The frequent regeneration cycle is not a major drawback in this application since waste heat from the catalyst system intercoolers is available to regenerate the desiccant.

\subsubsection{Drying System Design}

The desiccant drying system has been selected for use in the Purification Unit as the least complex and most economic of the low pressure dryers. The drying system has three desiccant towers, one of which is in service drying the process stream, one is being regenerated with hot air and one is being cooled after regeneration, prior to being placed in service.

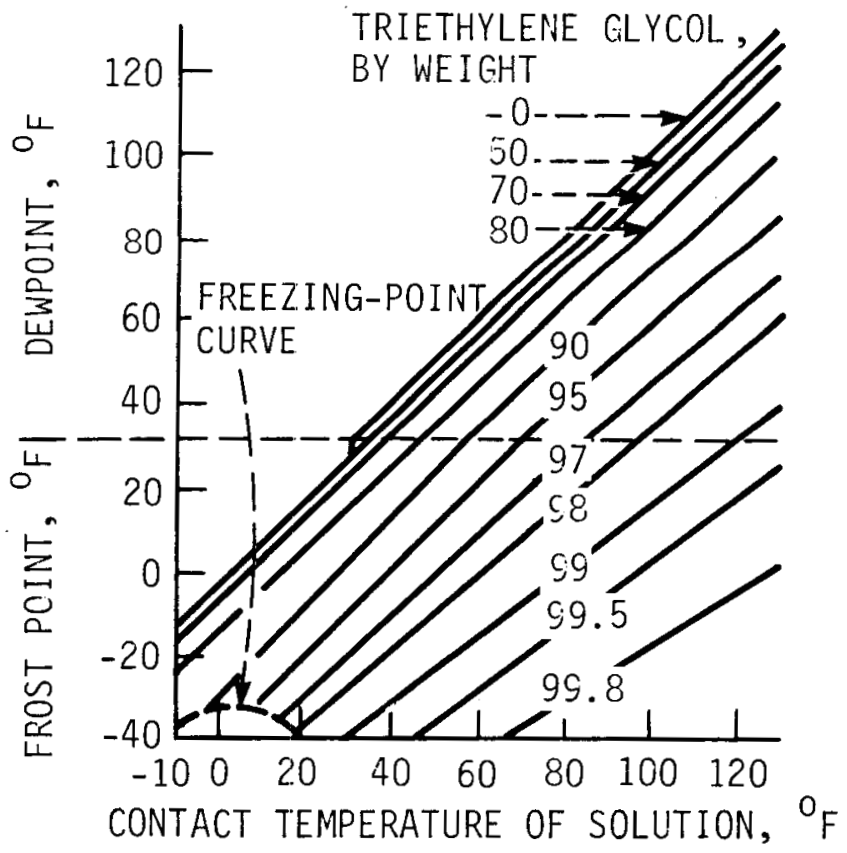

FIGURE 7. - Dewpoints of aqueous triethylene glycol solutions (ㅁ) . 
The desiccant towers have been sized for a 1-hr service period. The regeneration and cooling cycles will take a total of about 1.5 hr. Activated alumina has been selected as the desiccant since, unlike silica gel, it resists damage from water carryover and stands up well after multiple regeneration cycles. 


\section{DIESEL EXHAUST GAS PURIFICATION UNIT - SYSTEM DESCRIPTION}

The design of the system consists of three alternate process schemes, each based on a different method for gas drying. The combustor/converter and $\mathrm{CO}_{2}$ removal units are the same for all three schemes.

System descriptions for each of the three alternative systems are presented in this section. The system descriptions all include equipment arrangement drawings and process flow diagrams. The system description for the recommended system also contains a piping and instrumentation diagram. The three systems described in the following subsections are all guite similar, differing only in the manner in which the inert gas is dried.

In system I, all drying is performed with desiccant. This system meets all of the design specifications and is the recommended system. In system II, the drying is accomplished using a combined refrigeration/desiccant system. This system was investigated because of the reluctance of any gas drying equipment vendors to supply a purely desiccant system for this low pressure, high temperature application. As discussed in the following section of this report, this system is more complex mechanically and more expensive than the other systems analyzed. However, we felt it had to be explored to ensure that the standard low pressure gas drying approach was not the one best suited to this application. In system III, the process gas is compressed to 115 psig prior to $\mathrm{CO}_{2}$ removal and drying. Compression to this pressure causes most of the moisture in the gas to condense, simplifying the drying process, and increases the efficiency of the $\mathrm{CO}_{2}$ scrubbing process. This approach was the most economical but does not meet all of the system design specifications since it requires a process gas compressor to be used in lieu of the standard primary air compressor. System III could, therefore, not be used with standard air drilling compressor sets.

\subsection{System I - Desiccant Drying}

Refer to the process flow diagram (Figure 8), the equipment arrangement drawings (Figures 9, 10, and 11), and the piping and instrumentation diagram (Figure 12) to follow this system description.

The Diesel Exhaust Gas Purification system is a trailermounted, over-the-road, transportable system, which is capable of generating essential (98+ percent) pure nitrogen from diesel engine exhaust. The major components are: 


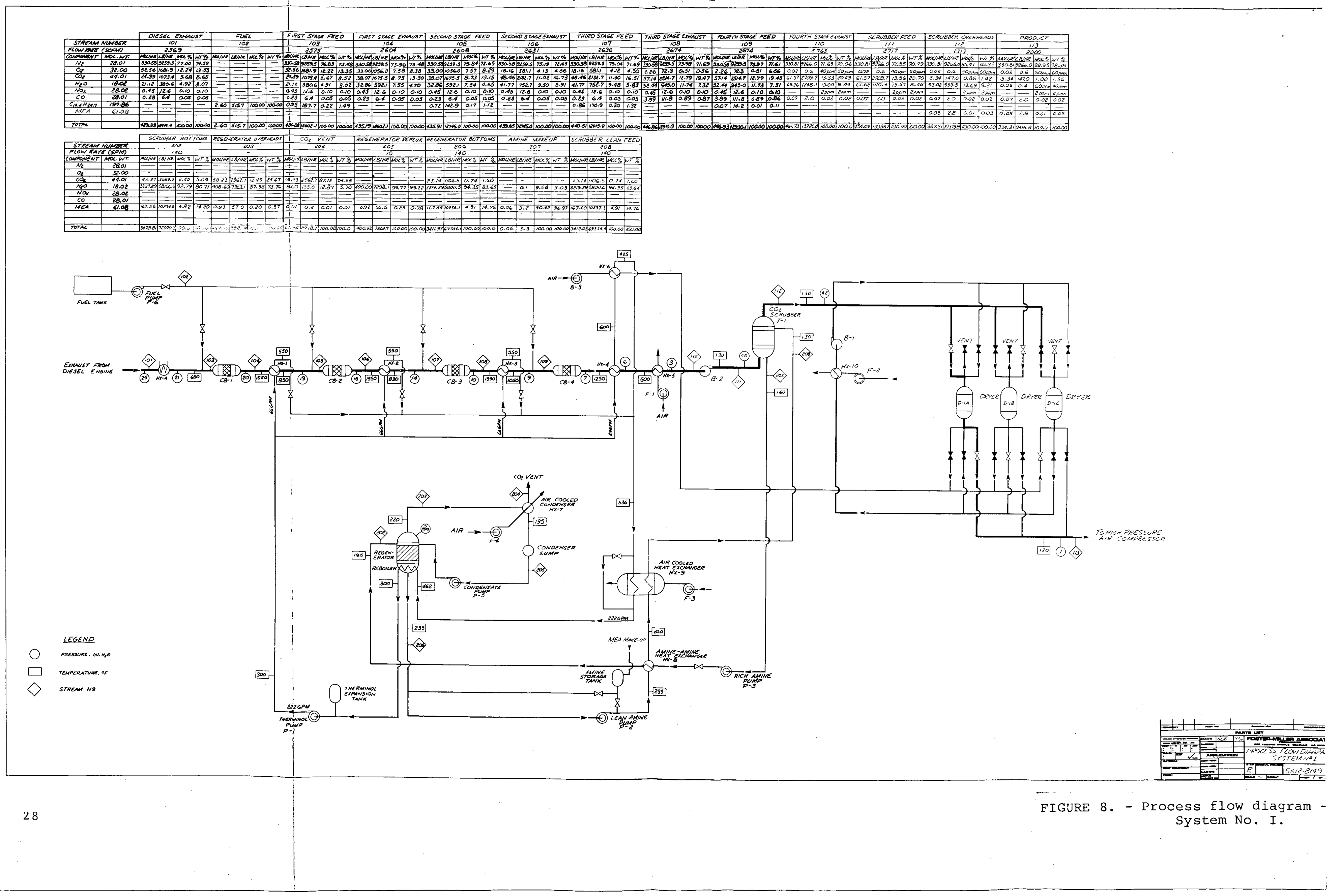



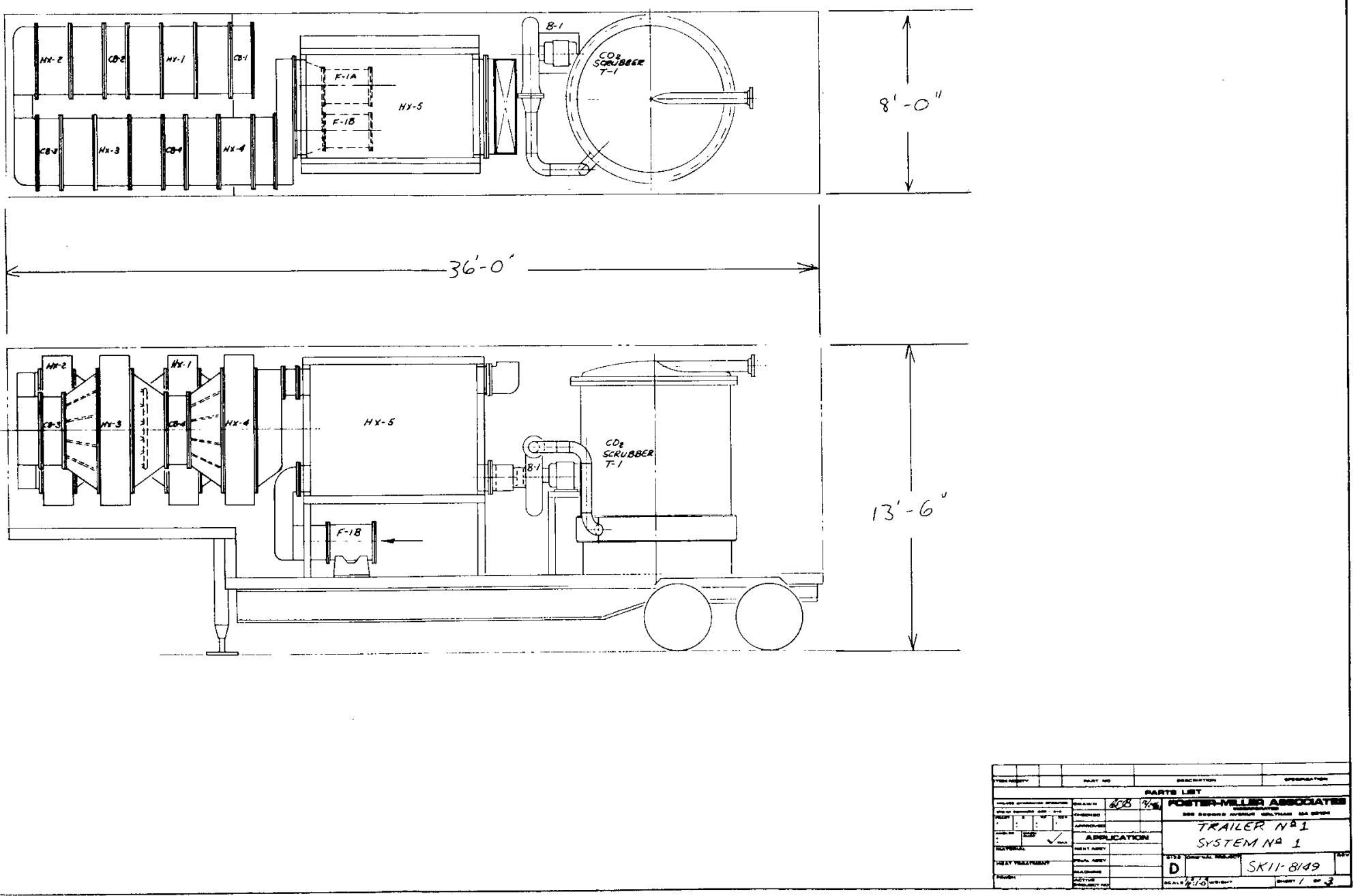

FIGURE 9. - Trailer No. 1 - System No. I. 

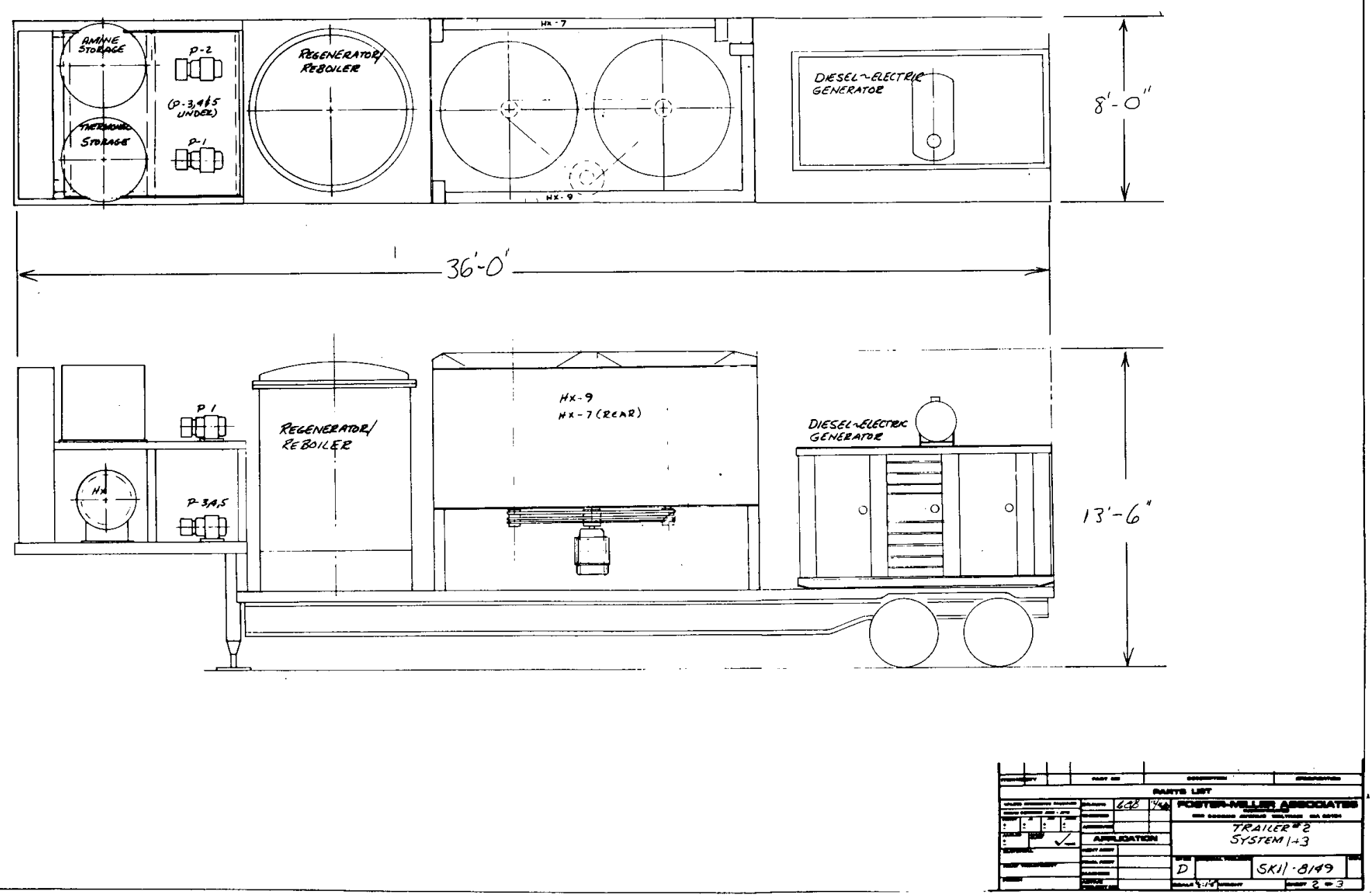

FIGURE 10. - Trailer No. 2 - System No. III. 

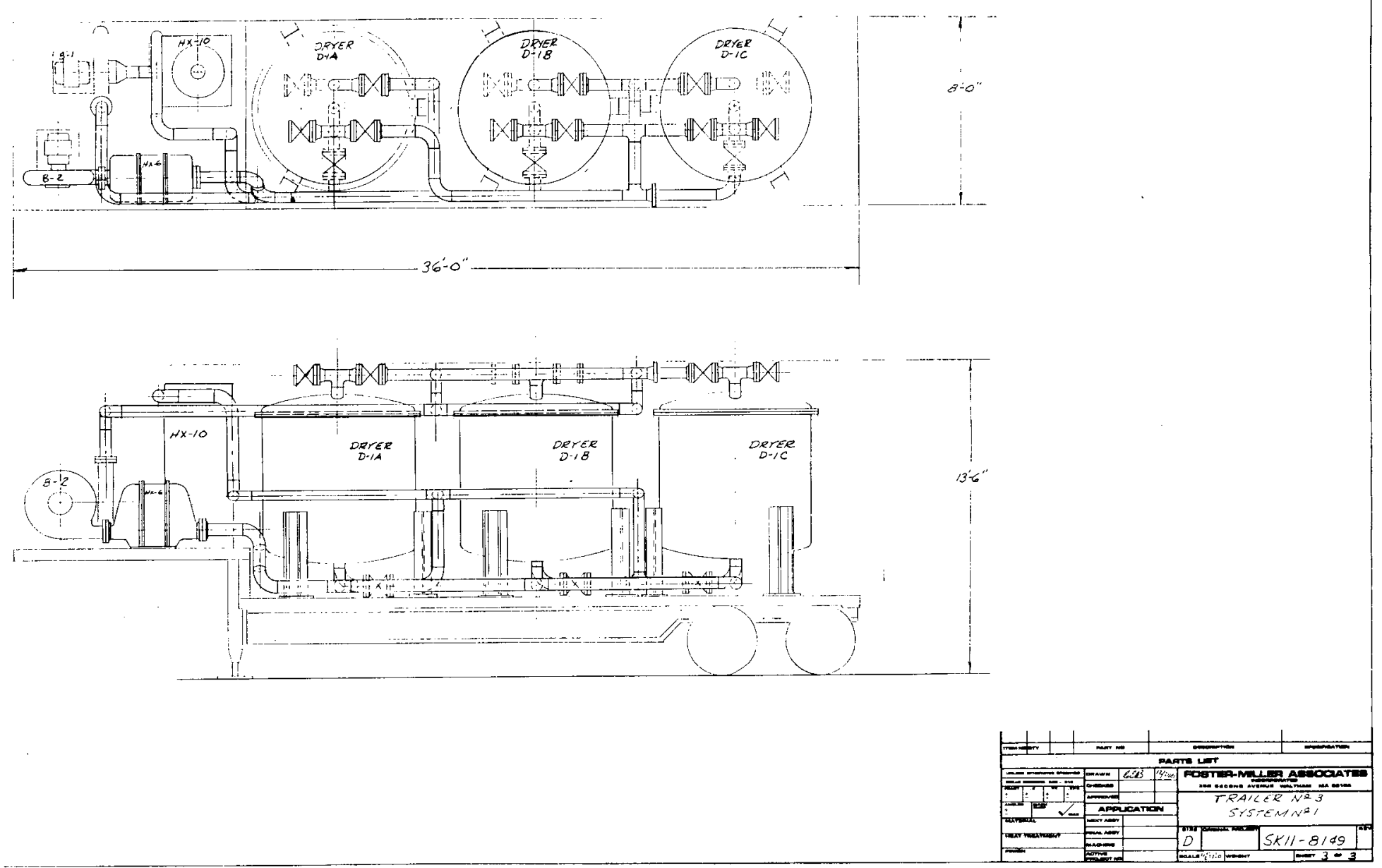

FIGURE 11. - Trailer No. 3 - System No. III. 


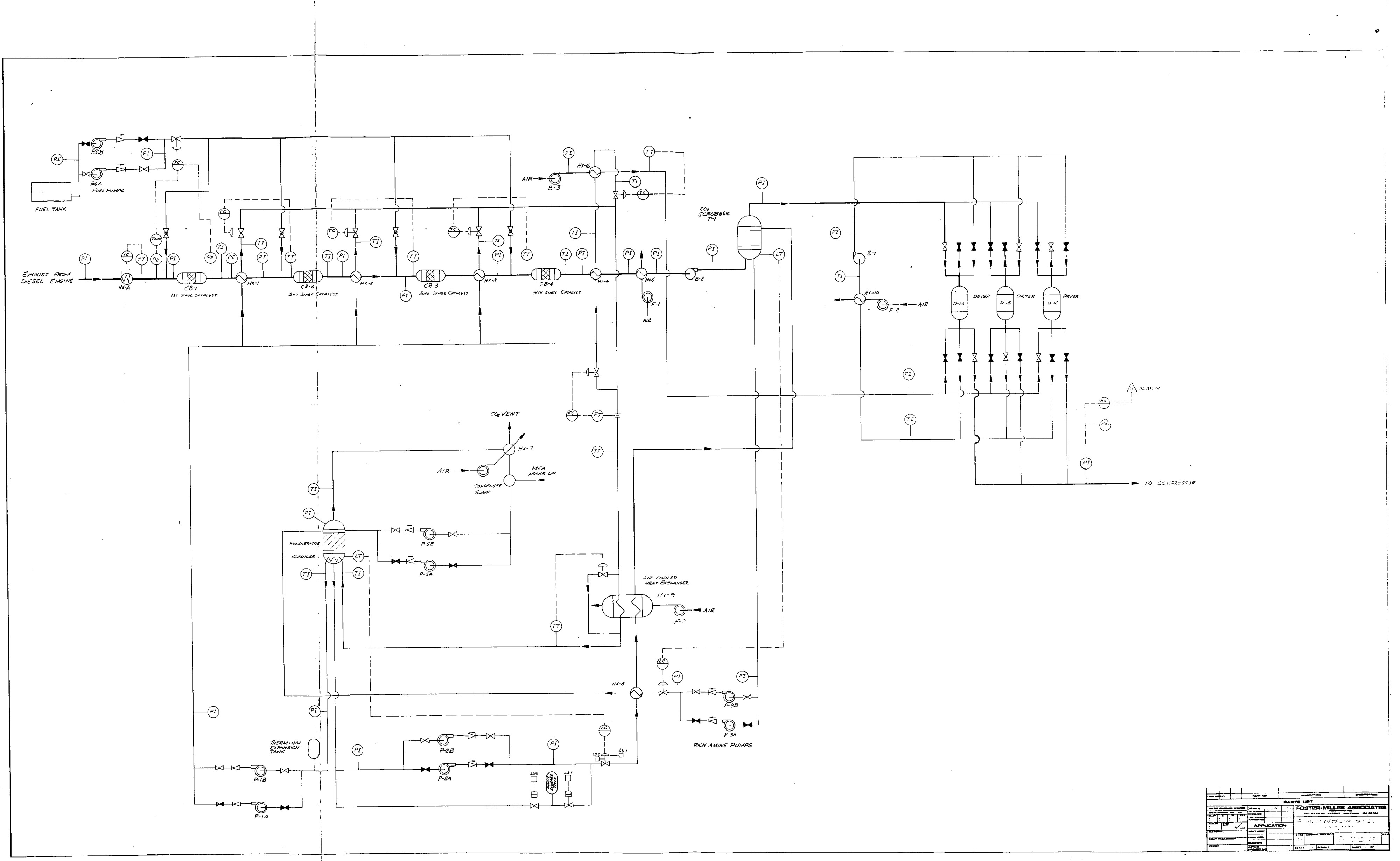


a. A four-stage catalytic combustor/converter which will remove up to 12 percent oxygen from the exhaust and maintain NOX and $\mathrm{O}_{2}$ levels below $2 \mathrm{ppm}$ and $50 \mathrm{ppm}$, respectively. A fifth stage may be desirable for certain diesels whose exhaust oxygen concentration generally remains above 10 percent.

b. A $\mathrm{CO}_{2}$ scrubber system which utilizes aqueous monoethanloamine (MEA) to reduce the $\mathrm{CO}_{2}$ concentration in the exhaust to $<1$ percent.

c. A desiccant andior refrigeration dryer which dries the saturated nitrocren exiting the $\mathrm{CO}_{2}$ scrubber to a dew point of $-55^{\circ} \mathrm{F}$.

The exhaust from the diesel engine is ducted to the inlet of the first stage catalytic combustor. A preheater is used to maintain the exhaust temperature at the $650^{\circ} \mathrm{F}$ required to ensure the desired reaction rate in the catalyst bed. The oxygen level of the exhaust gas is measured at this point and used to generate a set point for the fuel system. The fuel flow is distributed such that the oxygen is removed in the following manner:

\begin{tabular}{cl}
${ }^{\circ} \mathrm{O}_{2}$ removed & Catalyst \\
\hline 37.5 & lst stage \\
29.2 & 2nd stage \\
29.2 & 3rd stage \\
$\frac{4.1}{100.0}$ & 4 th stage
\end{tabular}

Therminol heat exchangers between each catalyst bed act as intercoolers to control the inlet temperature to the next catalyst stage thus controlling activity and maximum temperature in the catalyst bed. After exiting the 4 th stage catalyst converter the gas passes through a Therminol aftercooler and an air-cooled heat exchanger (scrubber precooler) which cool it to $130^{\circ} \mathrm{F}$.

At this point in the flow path, the gas is passed through a blower which increases the static pressure of the gas to that required by the scrubber and dryer and limits the back pressure on the diesel engine. The blower discharge is directed to the $\mathrm{CO}_{2}$ scrubber.

The $\mathrm{CO}_{2}$ scrubber consists of a packed, counterflow, MEA column. The use of high efficiency packing enables us to obtain the required column height while maintaining overall equipment height below the $13 \mathrm{ft} 6 \mathrm{in}$ road limit. MEA is used 
to absorb $\mathrm{CO}_{2}$ from the gas stream. The rich (high in $\mathrm{CO}_{2}$ ) $\mathrm{MEA}$ solution exits the bottom of the column and is pumped to the reboiler/regenerator where the heat picked up by the Therminol in catalyst inter/after coolers is used to strip the $\mathrm{CO}_{2}$ from the MEA. The lean (low in $\mathrm{CO}_{2}$ ) MEA from the regenerator bottoms is pumped through an air-cooled heat exchanger and back to the top of the scrubber column to continue the $\mathrm{CO}_{2}$ absorption process. The gas exiting the scrubber column, essentially watersaturated nitrogen, is directed to the dehydration unit.

The exhaust from the $\mathrm{CO}_{2}$ scrubber passes through one of three, $6 \mathrm{ft} 6 \mathrm{in}$. diam desiccant dryers. Because of the high water loading at atmospheric pressure, a triple-column drying unit is used. Each column will first absorb moisture, then regenerate, then cool. The sequence will be advanced by a series of time-actuated valves located at both ends of each dryer. The length of time for each sequence will be set by the operator depending upon the dryer inlet dewpoint.

Hot air for regeneration is provided by blowing ambient air across a heat exchanger through which hot Therminol from the catalytic combustor/converters is flowing. The regenerator air blows through the dryers counter-current to the process gas.

Cooling is provided by blowing gas through the regenerated desiccant bed counter-current to the regeneration air through a gas/gas heat exchanger in a closed loop.

A desiccant dryer was chosen for the dehydration unit because of its inherent simplicity and because it can utilize waste heat available from the catalytic combustor/converters. However, to remove the quantity of water present in the process gas stream at atmospheric pressure requires a very large desiccant bed (three trailers are necessary for all the equipment) and a very short drying cycle must be used.

\subsection{System II - Refrigeration Cooling and Desiccant Drying}

Refer to the process flow diagram (Figure 13) and the equipment arrangement drawings (Figures 14 and 15) to follow this system description.

The process flow for this system is the same as for system I through the $\mathrm{CO}_{2}$ scrubber. The gas drying process, which utilizes refrigeration and desiccant, is described in the following paragraphs. 


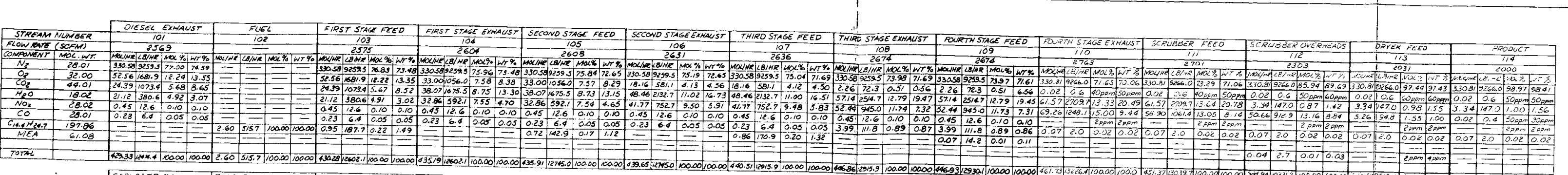

Trome

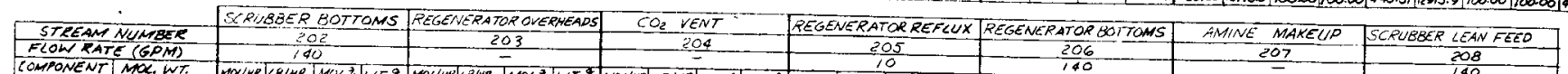

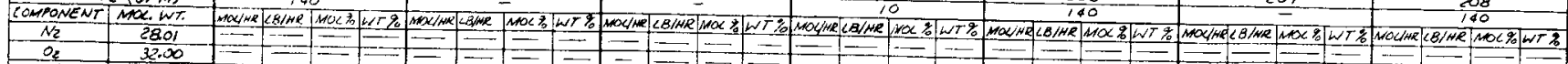

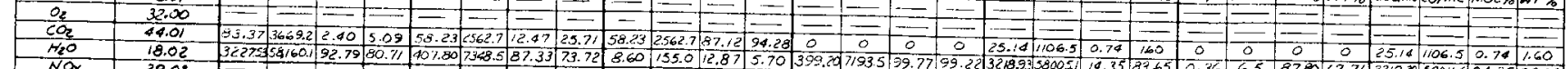

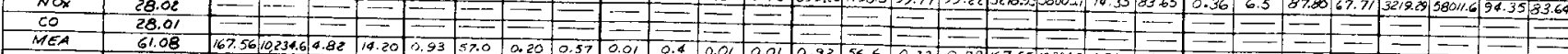

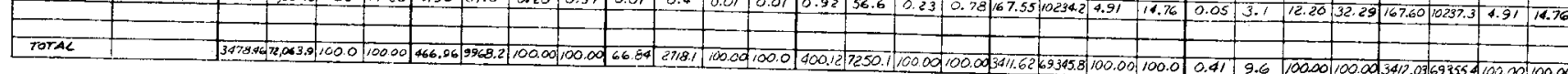

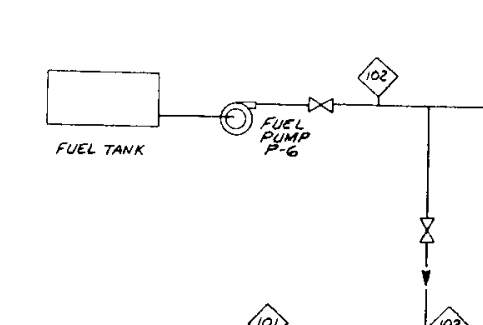

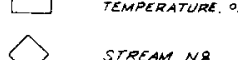

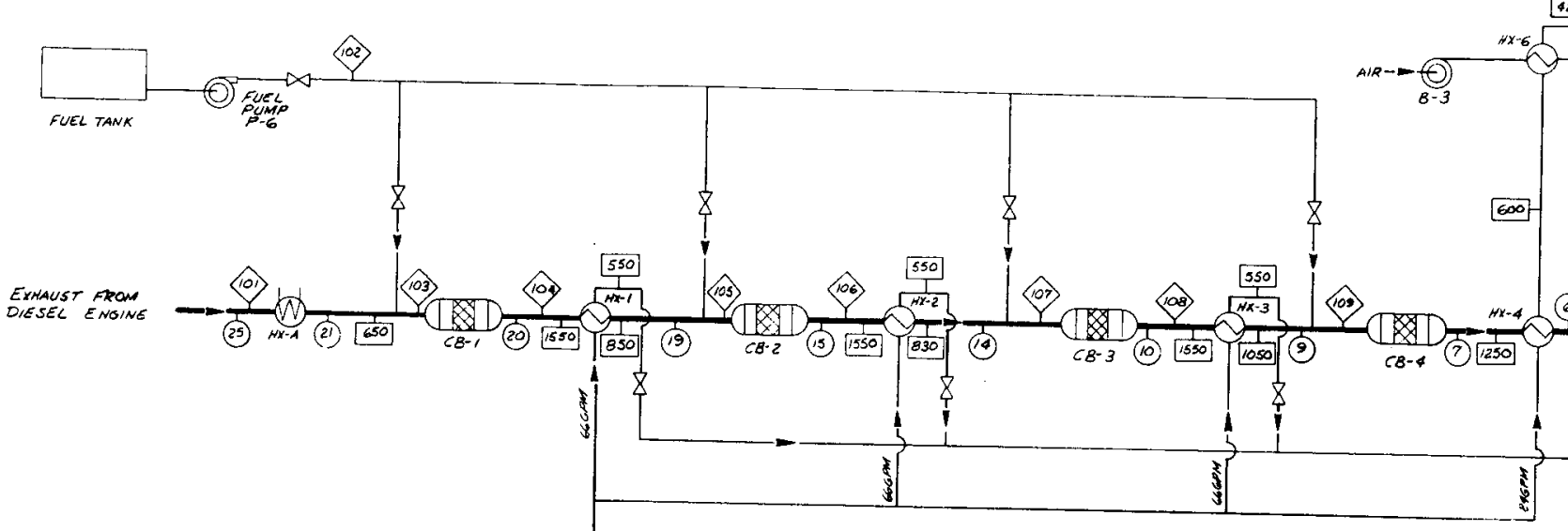
(3) (10) \} (9)

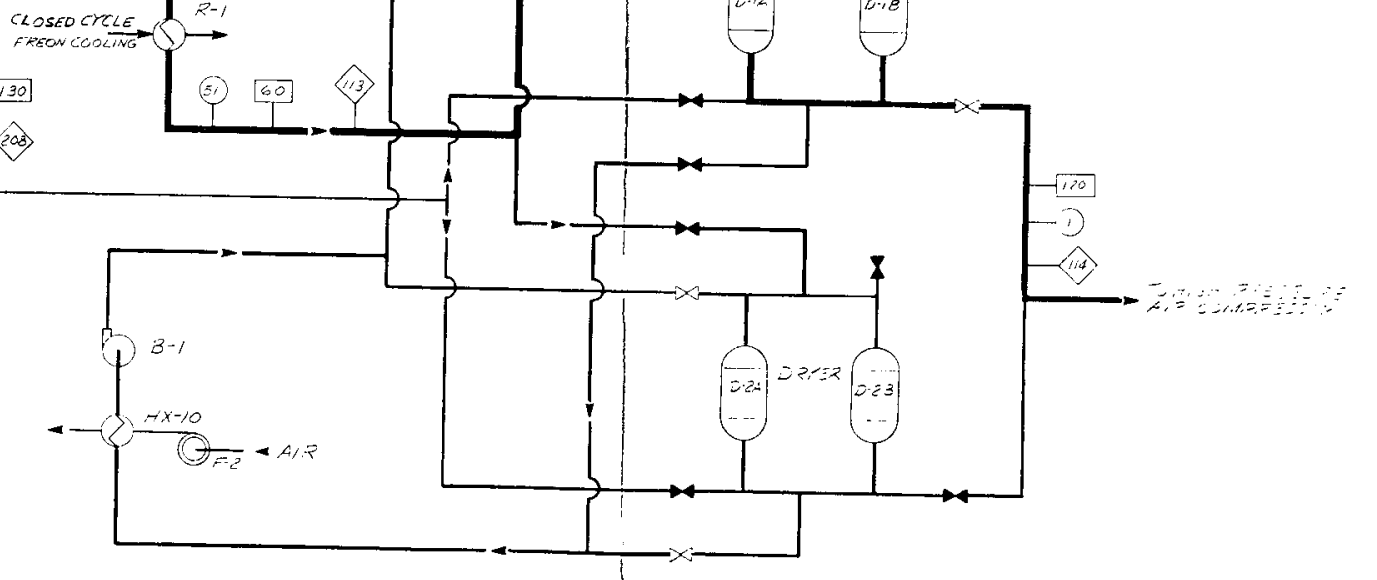
$500-$

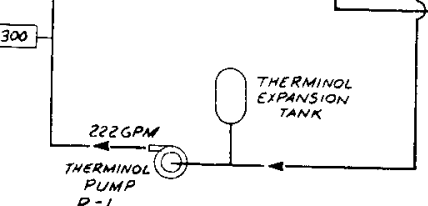

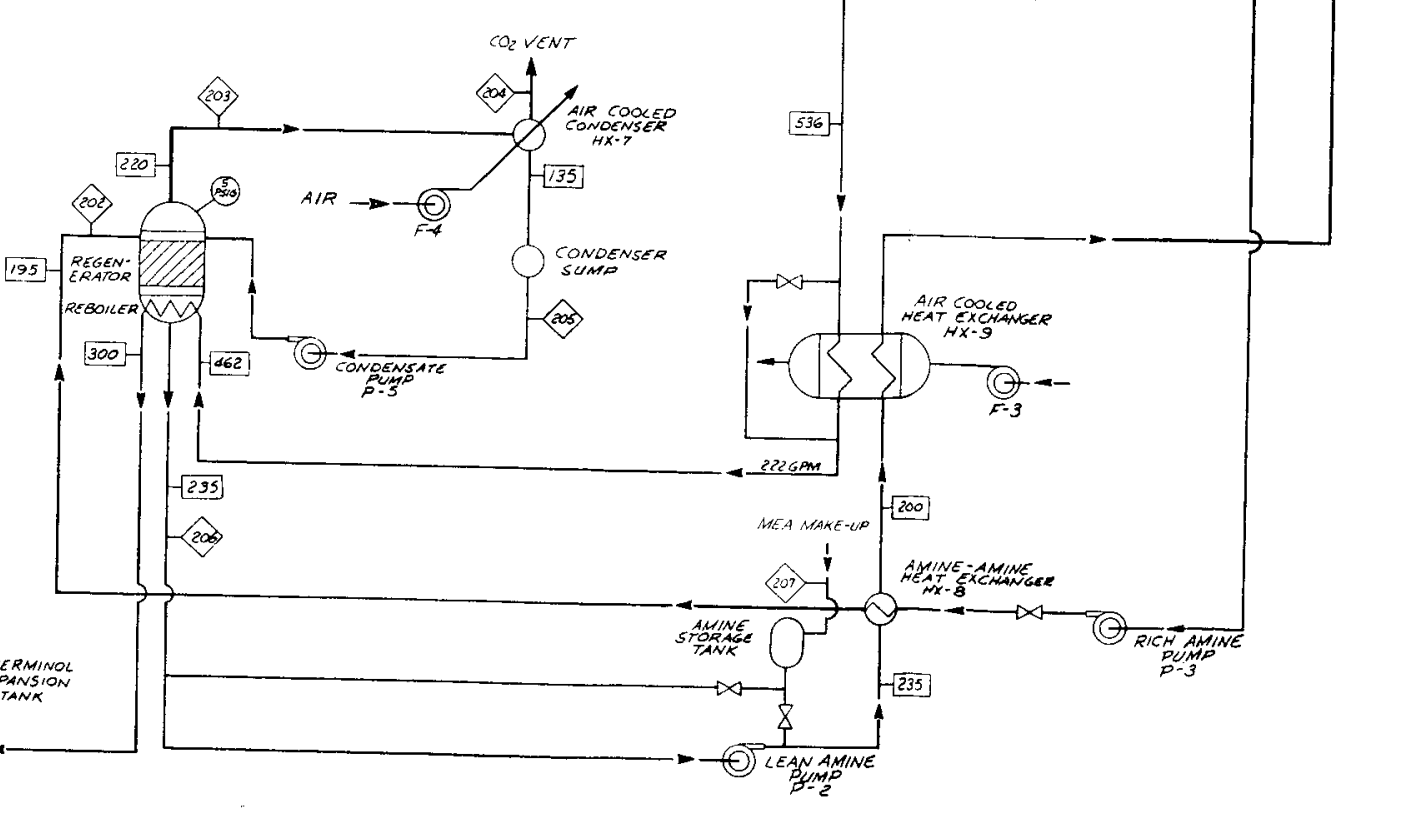




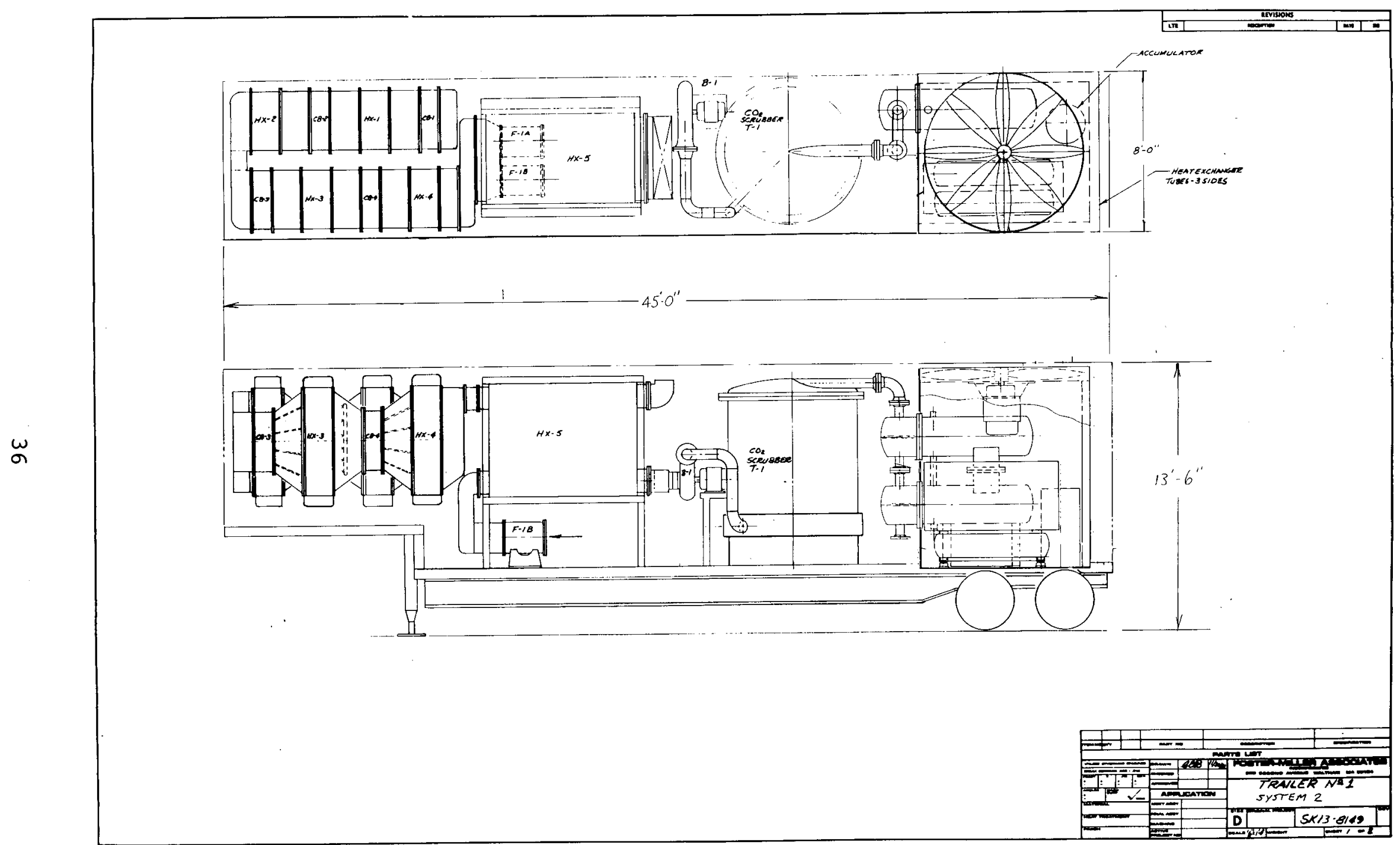

FIGURE 14. - Trailer No. 1 - System No. II. 


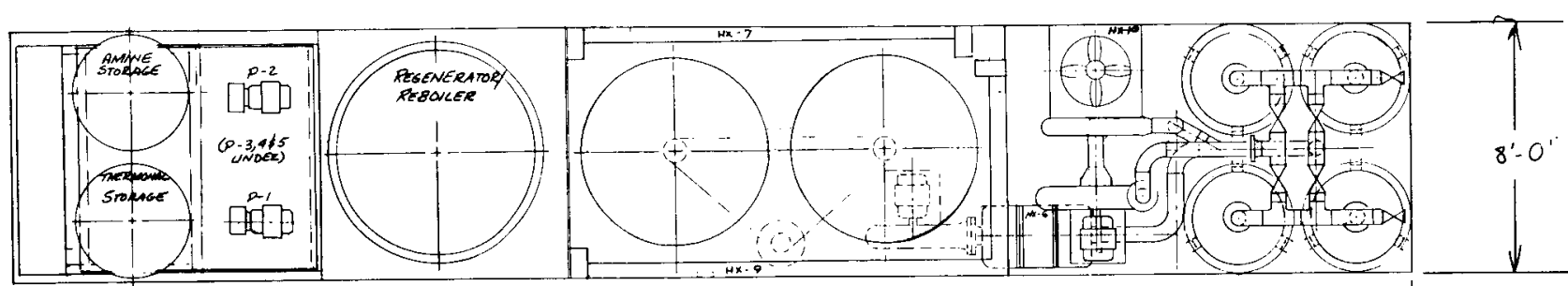

$-45^{\circ}-0^{\prime \prime}$
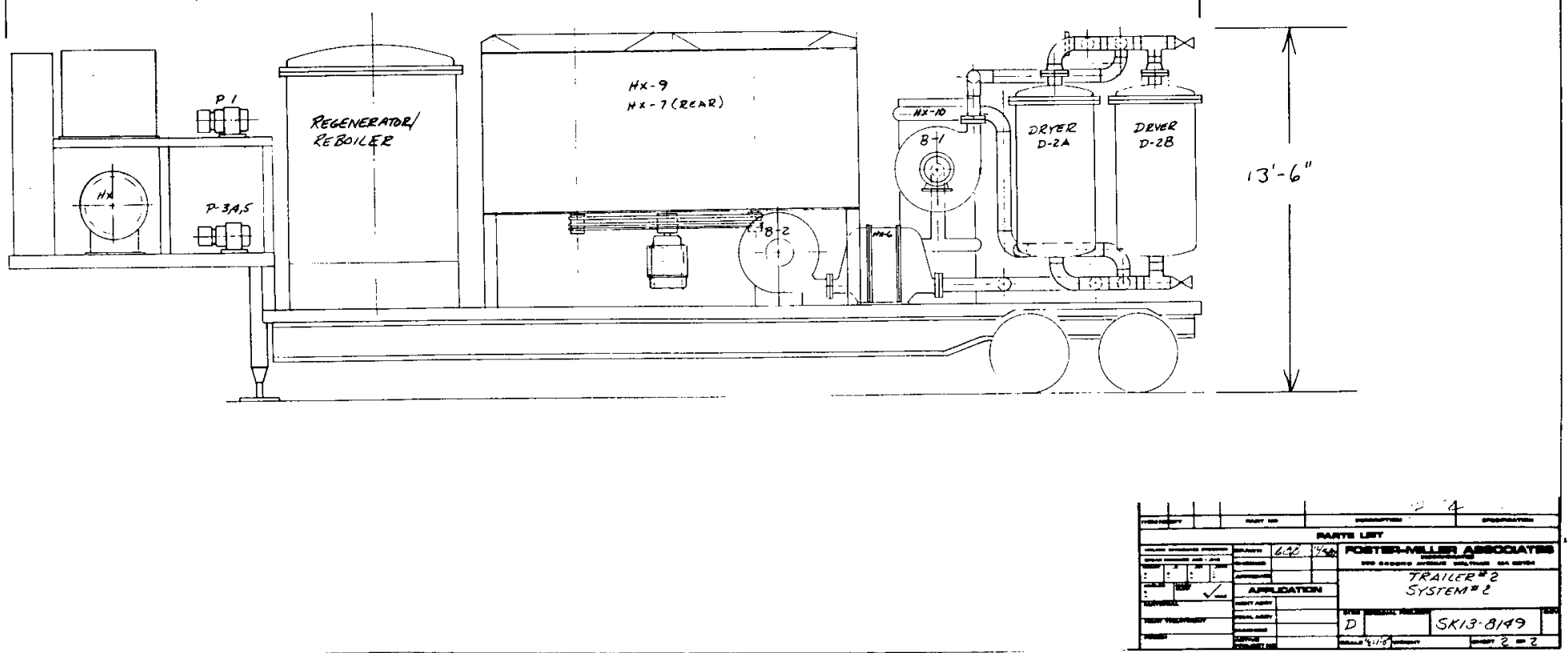

FIGURE 15. - Trailer No. 2 - System No. II. 
Dryer vendors contacted recommended using a combination refrigerator cooler and desiccant dryer to more efficiently remove the quantity of moisture present at atmospheric pressure. In this scheme, the exiting gas from the $\mathrm{CO}_{2}$ scrubber passes through the shell side of a closed-cycle, freon cooler, where it is cooled to $60^{\circ} \mathrm{F}$, reducing the moisture load from 13 percent to less than 2 percent. The process gas stream is then split and passes through two parallel, 3 ft 6 in. diam, dual-tower desiccant dryers where it is dried to the final $-55^{\circ} \mathrm{F}$ dewpoint.

Since there are only two drying paths per drying unit, instead of having one tower drying, one regenerating and one cooling, the sequence calls for one set of towers to dry until the second set of towers is finished both regenerating and cooling.

Although this dehydration scheme requires less space than System No. I (two drop bed trailers and a separate trailermounted diesel generator rather than three drop bed trailers), it does call for a larger auxiliary power source for the refrigeration cooler. This system also has a higher capital and operating cost than system I.

\subsection{System III - High Pressure $\mathrm{CO}_{2}$ Removal and Desiccant Drying}

Refer to the process flow diagram (Figure 16) and the equipment arrangement drawings (Figures 17 and 10) to follow this system description.

The process flow for this system is the same as for system I through the scrubber precooler $(\mathrm{HX}-5)$. The $\mathrm{CO}_{2}$ removal and gas dryjing processes which take place at high pressure are described below.

A straightforward approach to minimize space requirements without the use of additional power is to first compress the process gas and then dehydrate it. The compression will condense most of the water, and, since the product gas is to be compressed anyway, there is no additional power requirement.

In this system a process gas compressor is located upstream of the $\mathrm{CO}_{2}$ scrubber in place of the gas blower of system $I$. The process gas is passed directly from the scrubber precooler to a process gas compressor, where it is compressed to 115 psig. The compressor must be designed to handle a wet, acid gas. The gas is then sent to the $\mathrm{CO}_{2}$ scrubber. The scrubber exhaust is split into two parallel streams, each of which is dehydrated in a 


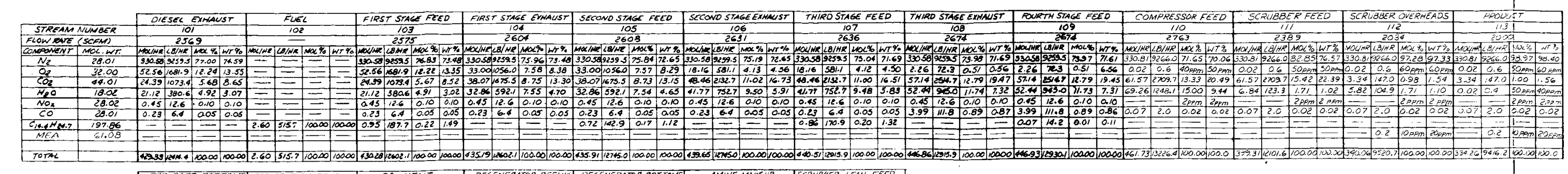

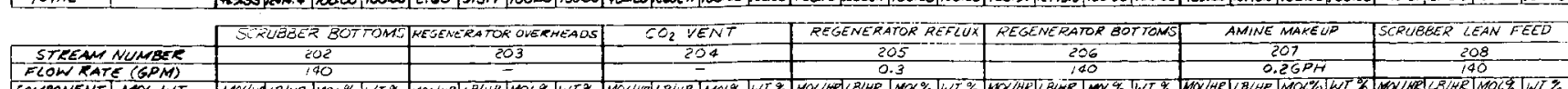

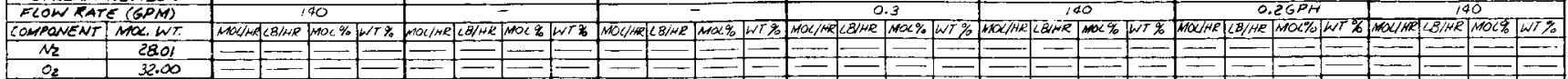

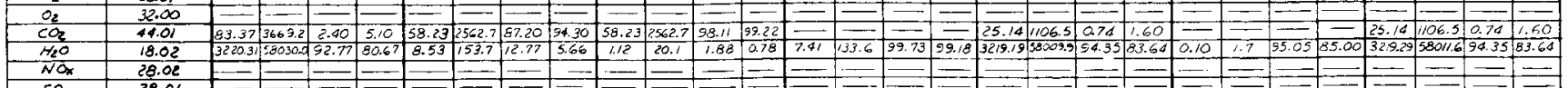

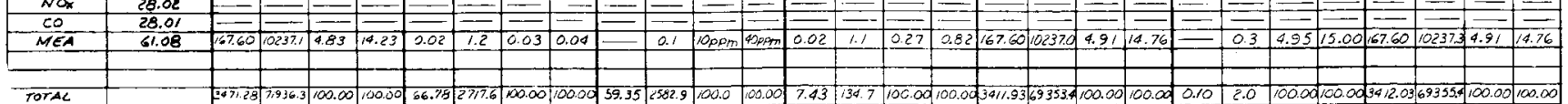

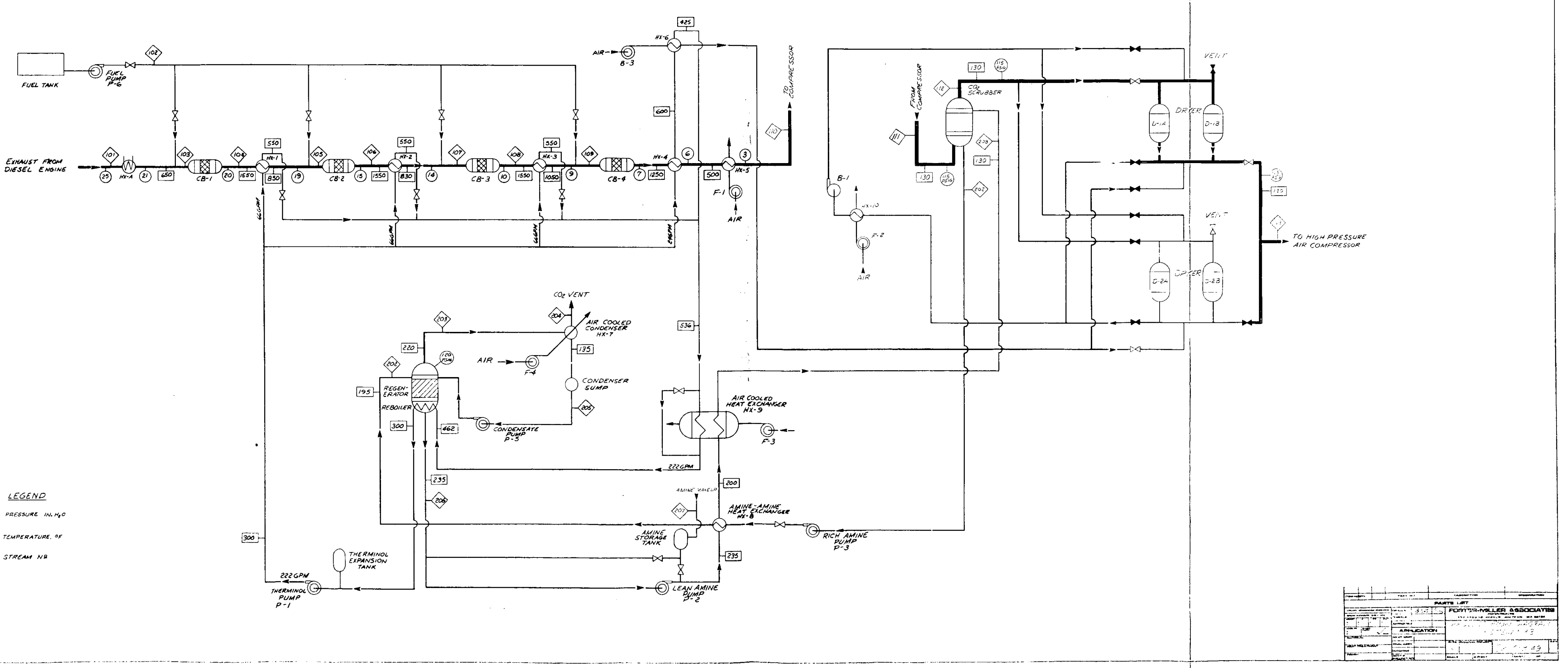

FIGURE 16. - process flow diagran system no. ici. 


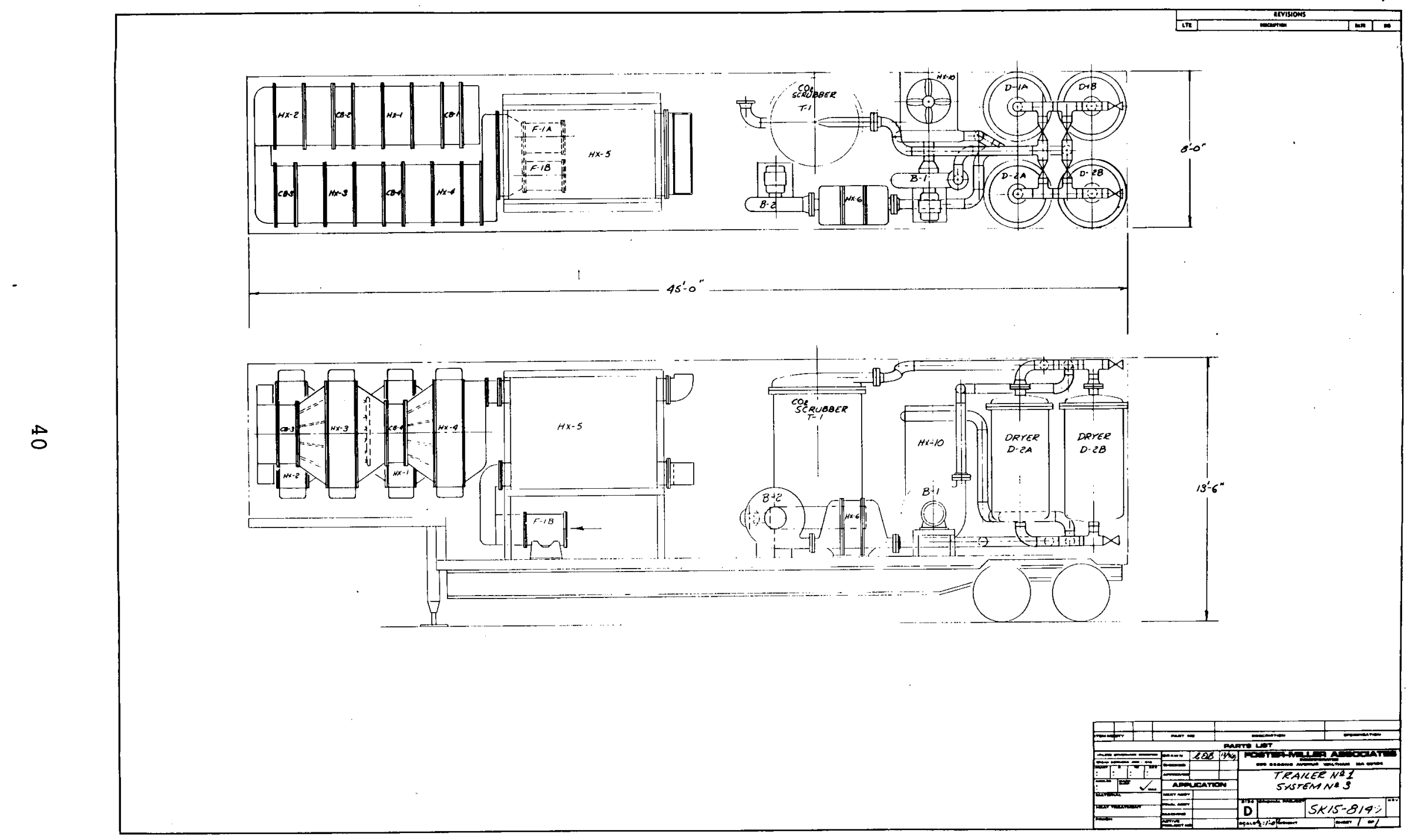

FIGURE 17. - Trailer No. 1 - system No. III. 
3 ft 6 in. diam, dual-tower desiccant dryer where the gas reaches its final $-55^{\circ} \mathrm{F}$ dewpoint. The drying cycle follows the same sequence described in System II.

This system incorporates a savings in equipment size compared to system I and a savings in power requirements compared to system II. Its disadvantage is the special compressor needed to compress the wet, acid gas. 


\section{SYSTEM ECONOMICS}

The capital, operating and maintenance costs of the three system configurations under consideration are presented in this section. System costs are compared on the basis of annual levelized life-cycle costs and cost to produce 1000 scf of $\mathrm{N}_{2}$ at various equipment utilization rates. All costs are in 1981 dollars.

\subsection{Capital Cost}

The capital costs of the various system arrangements are presented in this section. Both a single-unit and 100-unit production run are addressed. The capital cost is derived from the direct material costs (based on vendor quotes), estimated fabrication labor, and assumed labor burden, G\&A, warranty, and profit typical of the fabrication industry.

The assumed rates, which were slightly different for the single-unit and 100-unit cases, are presented in Table 2 . Based on the quotes that we received, it appears that equipment vendors would pass along engineering savings on multiple units and accept a smaller unit profit on a large order. This would result in a savings of approximately 10 percent of the direct cost. Similarly, the system fabricator could be expected to reduce his G\&A fee and accept a smaller profit on each unit if multiple units were ordered. In addition, multiple-unit production runs would result in more efficient labor utilization. These additional savings are also reflected in Table 2 .

TABLE 2. - Fabrication rates

\begin{tabular}{|l|c|c|}
\hline \multirow{2}{*}{ Direct material } & \multicolumn{2}{|c|}{ Production run size } \\
\cline { 2 - 3 } G\&A & Single unit & 100 units \\
\cline { 2 - 3 } Labor & Base & $90 \%$ of base \\
Labor Burden & $10 \%$ & $5 \%$ \\
Warranty & Base & $80 \%$ of base \\
Profit & $200 \%$ & $200 \%$ \\
& $5 \%$ & $5 \%$ \\
& $20 \%$ & $15 \%$ \\
\hline
\end{tabular}


The assumptions presented in Table 2 are used with the direct material costs and estimated labor costs to determine the total capital cost of each of the three system configurations under consideration. These costs are shown in Table 3 and are used with the following equation to determine the total capital cost of each system:

Total capital cost $=[$ (direct material) $(1+G \& A)$

$+($ direct labor $)(1+$ labor burden $)](1+\operatorname{warranty})(1+$ profit $)$

The total capital cost is then used to determine the annual capital expense for each system. The following equation was used:

$$
\text { Annual capital expense }=c \frac{d(1+d)^{n}}{(1+d)^{n}-1}
$$

where:

$$
\begin{aligned}
& \mathrm{C}=\text { total capital expense } \\
& \mathrm{d}=\text { interest rate (assumed to be } 18 \text { percent) } \\
& \mathrm{n}=\text { duration of amortization period (assumed to be } 8 \text { years) }
\end{aligned}
$$

The annual capital expense is also shown in Table 3 (single unit) and Table 4 (100 units).

\section{2 Operating Costs}

The operating cost of the exhaust gas purification system is made up of fuel and labor components with the fuel cost dominating. The fuel consumption varies with the oxygen content of the exhaust gas and with the system auxiliary power requirements. Thus, the fuel costs vary with type of diesel driving the compressors, 2- or 4-cycle, and the type of drying system employed.

The hourly fuel consumption of the various combinations of diesel and drying cycles is shown in Table 5. The portion of the annual operating cost attributable to fuel is also shown in Table 5 for each of the system/diesel combinations. This cost is based on 40 percent utilization and a cost of $\$ 1.10 /$ gal for diesel fuel for non-road use. Labor is the other major contributor to operating costs. We assume that the system will require full time attendance and that the operators will require a skill. level equivalent to the crew chief on a workover rig. With an assumed wage of $\$ 14 / \mathrm{hr}, 100$ percent overhead, and 40 percent utilization, the yearly labor cost is $\$ 98,112$ per rig. 
TABLE 3. - System capital cost (single unit) (\$)

\begin{tabular}{|c|c|c|c|}
\hline Equipment & $\begin{array}{l}\text { System I } \\
\text { desiccant } \\
\text { drying }\end{array}$ & $\begin{array}{c}\text { System II } \\
\text { refrigeration } \\
\text { and desiccant } \\
\text { drying }\end{array}$ & $\begin{array}{c}\text { System III } \\
\text { high pressure } \\
\text { desiccant } \\
\text { drying }\end{array}$ \\
\hline \multicolumn{4}{|l|}{ Catalyst bed } \\
\hline $\mathrm{CB}-1$ & $\$ 16,000$ & $\$ 16,000$ & $\$ 16,000$ \\
\hline $\mathrm{CB}-2$ & 16,000 & 16,000 & 16,000 \\
\hline $\mathrm{CB}-3$ & 16,000 & 16,000 & 16,000 \\
\hline $\mathrm{CB}-4$ & 16,000 & 16,000 & 16,000 \\
\hline Catalyst system ducts & 10,000 & 10,000 & 10,000 \\
\hline $\mathrm{CO}_{2}$ scrubber & 61,000 & 61,000 & 41,000 \\
\hline Regenerator & 38,000 & 38,000 & 26,000 \\
\hline Gas dryer & 150,000 & 208,000 & 100,000 \\
\hline \multicolumn{4}{|l|}{ Heat exchangers } \\
\hline $\mathrm{HXA}$ & 5,000 & 5,000 & 5,000 \\
\hline $\mathrm{HXI}$ & 7,000 & 7,000 & 7,000 \\
\hline $\mathrm{HX} 2$ & 7,000 & 7,000 & 7,000 \\
\hline $\mathrm{HX} 3$ & 6,000 & 6,000 & 6,000 \\
\hline $\mathrm{HX} 4$ & 7,000 & 7,000 & 7,000 \\
\hline $\mathrm{HX} 5$ & 30,000 & 30,000 & 30,000 \\
\hline $\mathrm{HX} 6$ & 10,000 & 10,000 & 10,000 \\
\hline $\mathrm{HX} 7$ & 25,000 & 25,000 & 25,000 \\
\hline $\mathrm{HX} 8$ & 11,000 & 11,000 & 11,000 \\
\hline HX9 & 45,000 & 45,000 & 45,000 \\
\hline $\mathrm{HX1O}$ & 10,000 & 10,000 & 10,000 \\
\hline Reboiler & 20,000 & 20,000 & 20,000 \\
\hline \multicolumn{4}{|l|}{ Pumps (2 each) } \\
\hline Therminol P1 & 2,700 & 2,700 & 2,700 \\
\hline Lean amine P2 & 4,700 & 4,700 & 4,700 \\
\hline Rich amine P3 & 4,000 & 4,000 & 4,000 \\
\hline Condensate P5 & 900 & 900 & 900 \\
\hline Fue1 F6 & 800 & 800 & 800 \\
\hline
\end{tabular}


TABLE 3. - System capital cost (single unit) (\$) (continued)

\begin{tabular}{|c|c|c|c|}
\hline Equipment & $\begin{array}{c}\text { System I } \\
\text { desiccant } \\
\text { drying }\end{array}$ & $\begin{array}{c}\text { System II } \\
\text { refrigeration } \\
\text { and desiccant } \\
\text { drying }\end{array}$ & $\begin{array}{c}\text { System III } \\
\text { high pressure } \\
\text { desiccant } \\
\text { drying }\end{array}$ \\
\hline Blower Bl & 7,500 & - & $\$-$ \\
\hline Blower B2 & 5,000 & 5,000 & 5,000 \\
\hline Moisture separator & - & 3,000 & - \\
\hline Condensate sump & 500 & 500 & 500 \\
\hline Fuel tank & 500 & 500 & 500 \\
\hline Therminol tank & 500 & 500 & 500 \\
\hline Amine $\operatorname{tank}$ & 500 & 500 & 500 \\
\hline Trailer 1 & 15,000 & 18,000 & 18,000 \\
\hline Trailer 2 & 15,000 & 18,000 & 18,000 \\
\hline Trailer 3 & 18,000 & - & - \\
\hline Diesel generator & 28,000 & 38,000 & 22,000 \\
\hline $\begin{array}{l}\text { Instruments and } \\
\text { controls }\end{array}$ & 85,000 & 85,000 & 85,000 \\
\hline Piping and insulation & 45,000 & 40,000 & 36,000 \\
\hline Total direct material & 739,600 & 787,600 & 623,100 \\
\hline $\mathrm{G} \& \mathrm{~A}$ at $10 \%$ & 73,960 & 78,760 & $62,31.0$ \\
\hline Labor at $\$ 10 / \mathrm{hr}$ & 15,000 & 15,000 & 13,000 \\
\hline \multirow[t]{2}{*}{ Labor burden (200\%) } & 30,000 & 30,000 & 26,000 \\
\hline & 858,560 & 911,360 & 724,410 \\
\hline \multirow[t]{2}{*}{ Warranty $(5 \%)$} & 42,928 & 45,568 & 36,220 \\
\hline & 901,488 & 956,928 & 760,630 \\
\hline Profit $(20 \%)$ & 225,372 & 239,232 & 190,157 \\
\hline Total capital cost & $\$ 1,1.26,860$ & $\$ 1,196,162$ & $\$ 950,788$ \\
\hline Annual capital cost & $\$ 276,080$ & $\$ 293,059$ & $\$ 232,943$ \\
\hline
\end{tabular}


TABLE 4. - System Capital Cost (100 units)

\begin{tabular}{|c|c|c|c|}
\hline & $\begin{array}{c}\text { System } \\
\text { I }\end{array}$ & $\begin{array}{l}\text { System } \\
\text { II }\end{array}$ & $\begin{array}{l}\text { System } \\
\text { III }\end{array}$ \\
\hline Total direct cost & $\$ 665,640$ & $\$ 708,840$ & $\$ 560,790$ \\
\hline G\&A at $5 \%$ & 33,282 & 35,442 & 28,039 \\
\hline Labor at $\$ 10 / \mathrm{hr}$ & 12,000 & 12,000 & 10,400 \\
\hline Labor burden (200\%) & 24,000 & 24,000 & 20,800 \\
\hline Direct subtotal & 734,922 & 780,282 & 620,029 \\
\hline \multirow[t]{2}{*}{ Warranty $(5 \%)$} & 36,746 & 39,014 & 31,001 \\
\hline & 771,668 & 819,296 & 651,030 \\
\hline Profit $(15 \%)$ & 135,813 & 144,196 & 114,581 \\
\hline Total capital cost & $\$ 907,481$ & $\$ 963,492$ & $\$ 765,612$ \\
\hline Annual capital cost & $\$ 222,333$ & $\$ 236,055$ & $\$ 187,575$ \\
\hline
\end{tabular}

TABLE 5. - Fuel consumption gal/hr

\begin{tabular}{|c|c|c|}
\hline \multirow[b]{2}{*}{ System } & \multicolumn{2}{|c|}{ Diesel type } \\
\hline & $\begin{array}{c}2 \text { cycle } \\
11 \% \mathrm{O}_{2}\end{array}$ & $\begin{array}{l}4 \text { cycle } \\
6.5 \% \mathrm{O}_{2}\end{array}$ \\
\hline $\begin{array}{l}\text { System I } \\
\text { (desiccant) } \\
150 \mathrm{~kW}\end{array}$ & $\begin{array}{l}70.6 \mathrm{gal} / \mathrm{hr} \\
(\$ 272,120)\end{array}$ & $\begin{array}{l}46.7 \mathrm{gal} / \mathrm{hr} \\
(\$ 180,000)\end{array}$ \\
\hline $\begin{array}{l}\text { System II } \\
\text { (refrigerant and } \\
\text { desiccant) } \\
250 \mathrm{~kW}\end{array}$ & $\begin{array}{l}78.7 \mathrm{gal} / \mathrm{hr} \\
(\$ 303,34 \mathrm{l})\end{array}$ & $\begin{array}{l}54.8 \mathrm{gal} / \mathrm{hr} \\
(\$ 211,221)\end{array}$ \\
\hline $\begin{array}{l}\text { System III } \\
\text { (high pressure } \\
\text { desiccant) } \\
100 \mathrm{~kW}\end{array}$ & $\begin{array}{l}66.5 \mathrm{gal} / \mathrm{hr} \\
(\$ 256,317)\end{array}$ & $\begin{array}{l}42.6 \mathrm{gal} / \mathrm{hr} \\
(\$ 164,197)\end{array}$ \\
\hline
\end{tabular}




\subsection{Maintenance Costs}

Maintenance costs for each system configuration have been estimated and are presented in Table 6. The major contributor to the maintenance cost is the expense of replacing the catalyst. Catalyst life has been estimated from the data in Figure 4 for both the 11 percent and 6.5 percent oxygen cases. With 11 percent oxygen in the diesel exhaust, the maximum catalyst temperature is $1480^{\circ} \mathrm{F}$ which corresponds to a $6000-\mathrm{hr}$ life. The 6.5 percent oxygen case has an $1180^{\circ} \mathrm{F}$ maximum catalyst temperature which corresponds to a 17,000-hr life. This dramatic increase in catalyst life yields savings of almost $\$ 20,000 /$ year in catalyst replacement costs. Attempts to extend the catalyst life in the ll-percent oxygen case by using additional catalyst stages to reduce the operating temperature did not produce significant savings ( $\$ 1000 /$ year) because of the high cost of capital. The maximum number of catalyst stages will be limited by allowable diesel backpressure; the four stages used in this design are compatible with most diesels used in air drilling applications (the Waukesha being the known exception). Other significant maintenance costs are those associated with amine makeup and desiccant replacement. The amine hourly makeup requirement is obtained from the process flow diagrams and figured for one year at 40 percent utilization at a bulk cost of $\$ 0.64 / 1 b$. It has been assumed that the desiccant will have to be replaced once every 3 years. The desiccant cost is $\$ 1.00 / 1 b$.

TABLE 6. - Yearly maintenance cost

\begin{tabular}{|l|r|r|r|}
\hline \multicolumn{1}{|c|}{ System } & I & II & III \\
\hline Catalyst* & $\$ 31,500$ & $\$ 31,500$ & $\$ 31,500$ \\
Desiccant & 7,500 & 2,500 & 2,500 \\
Amine & 7,400 & 21,500 & 4,500 \\
Major components** & 16,500 & 20,000 & 16,500 \\
Labor & 4,000 & 4,000 & 4,000 \\
Miscellaneous & 5,000 & 5,000 & 5,000 \\
hardware & & & $\$ 64,000$ \\
\hline Total $11 \% \mathrm{O}_{2}$ & 571,900 & $\$ 84,500$ & 46,000 \\
\hline \multicolumn{2}{|c|}{$6.5 \% \mathrm{O}_{2}$} & 63,900 & in diesel exhaust; 6.5 percent case $\$ 13,500 /$ year. \\
\hline
\end{tabular}


Additional allowances have been made for replacement of the process gas blower, and amine pump and control valves annually. It has been assumed that a major portion of the maintenance will be accomplished in the field, but an allowance of 3 man weeks/year has been made to accommodate heat exchanger cleaning and major component replacement.

\subsection{Nitrogen Production Cost}

In this section the cost of producing 1000 scf of nitrogen is calculated for each of the 12 combinations of system arrangement, exhaust oxygen concentration, and single- or 100-unit production run. The cost per 1000 scf was calculated by dividing the sum of the annual capital expense, operating and maintenance costs explained in the previous subsections by the total gas produced (in thousands of cubic feet) during the year. A system utilization of 40 percent, equivalent to $16 \mathrm{hr} /$ day for $18 \mathrm{day} /$ month was assumed. It was also assumed that the system produced $2000 \mathrm{scfm}$ whenever operating. The single-unit and 100-unit production costs are presented in Table 7. The following equation was used to determine the nitrogen production costs:

Nitrogen production cost $(\$ / M s c f)=$

annual capital + annual maintenance + annual labor + annual fuel 2 Mscfm $\times 16 \frac{\mathrm{hr}}{\mathrm{day}} \times 18 \frac{\mathrm{day}}{\text { month }} \times 12 \frac{\mathrm{month}}{\mathrm{yr}} \times 60 \frac{\mathrm{min}}{\mathrm{hr}}$

TABLE 7. - Production cost, $\$ / M$ scf nitrogen

\begin{tabular}{|c|c|c|c|c|c|c|}
\hline \multirow[b]{2}{*}{ System arrangement } & \multicolumn{2}{|c|}{ I } & \multicolumn{2}{|c|}{ II } & \multicolumn{2}{|c|}{ III } \\
\hline & Single & 100-Unit & Single & 100-Unit & Single & 100-Unit \\
\hline $11 \% \mathrm{O}_{2}$ (2 cycle) & 1.73 & 1.60 & 1.89 & 1.74 & 1.57 & 1.46 \\
\hline $6.5 \% \mathrm{O}_{2}$ (4 cycle) & 1.46 & 1.34 & 1.61 & 1.48 & 1.31 & 1.20 \\
\hline
\end{tabular}




\section{REFERENCES}

1. Caskey, B.C. and K.S. Copass, "Drill Pipe Corrosion Control Using an Inert Drilling Fluid," Proceedings, International Conference on Geothermal Drilling and Completion Technology, Albuquerque, NM, January 21-23, 1981, (SAND 81-0036C, Paper 28-1 available from NTIS).

2. Osgerby, I.T. and M. Durilla, "Inert Gas Generation Utilizing Diesel Exhaust," Proceedings, International Conference on Geothermal Drilling and Completion Technology, Albuquerque, NM, January 21-23, 1981 (SAND 81-0036C, Paper 29-1 available from NTIS).

3. Olson, B.A., H.C. Lee, I.T. Osgerby, R.M. Heck and H. Hess, "Durability Testing at 5 Atmospheres of Advanced Catalysts and Catalyst Supports for Gas Turbine Engine Combustors," NASA CR-159839, 1980.

4. Heck, R.M., M. Chang, H. Hess and T. Mroz, "Durability Testing of Advanced Catalysts and Catalyst Supports for Gas Turbine Engine Combustors," AIChE Symposium Series No. 188, Vol. 75, 1979 .

5. Kohl, A. and F. Riesenfeld, Gas Purification, third edition, Gulf Publishing Co., Houston, TX, 1979 .

6. Davis, K.G. and K.D. Manchanda, "Unit Operations for Drying Fluids, " Chemical Engineering, September 61, 1974. 


\section{APPENDIX}

POTENTIAL VENDORS FOR MAJOR SYSTEM COMPONENTS

(typical, not sole source)

\author{
Catalyst \\ $\mathrm{CO}_{2}$ Scrubber \\ Heat Exchangers \\ (gas to air) \\ (gas to liquid) \\ (liquid to air) \\ Pumps
}

Blowers

Trailers

Diesel Generator
METPRO COIP.

P.O. Box 144

Harleysville, PA 19438

United Catalyst, Inc.

P.O. Box 32370

Louisville, KY 40232

Koch Engineering Co., Inc.

4111 East 37th Street

North Wichita, KS 67208

Des Champs Laboratories, Inc.

P.O. Box 348

East Hanover, NJ 07936

Ecodyne MRM Division

607 First Street, S.W.

Massilion, OH 44646

Worthington Pump, Inc.

A McGraw-Edison Company

270 Sheffield street

Mountainside, NJ 07092

Buffalo Forge Company

465 Broadway

Buffalo, NY 14240

Roots Blower Operation

Dresser Industries, Inc.

$900 \mathrm{~W}$. Mount Street

Connersville, ID 47331

Hyster Company

Construction Equipment Division

2000 Kentville Road

Kewanee, IL 61443

Birmingham Manufacturing Co., Inc. P.O. Box 289

Springville, AL 35146

Caterpillar Tractor Company

100 N.E. Adams

Peoria, IL 61629 


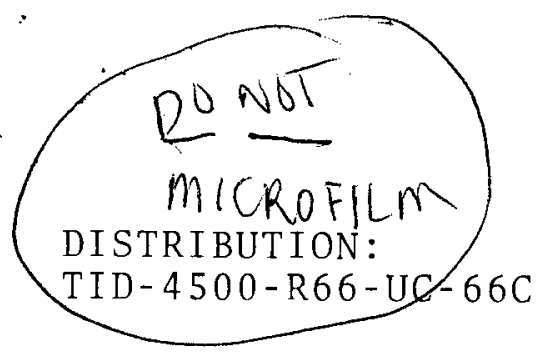

Tom Anderson

Venture Innovations

P.0. Box 35845

Houston, Texas 77035

Ed Bingman

She1l Oil Company

Two Shell Plaza

P.O. Box 2099

Houston, Texas 77011

Larry Diamond

Technical Services

Dyna-Drill

P.O. Box C-19576

Irvine, California 92713

John E. Fontenot

NL Petroleum Services

P.O. Box 60087

Houston, Texas 77205

Dr. Melvin Friedman

Professor of Geology

Center for Tectonophysics and Dept. of Geology

Texas A\&M University

College Station, Texas 77843

Tom Turner

Phillips Petroleum Company

Geothermal Operations

655 East 4500 South

Salt Lake City, Utah 84107

Jim Kingsolver, Manager

Geothermal Operations

Smith Tool

P.O. Box C-19511

Irvine, California 92713

James W. Langford

Security Division

Dresser Industries, Inc.

P.O. Box 24647

Dallas, Texas 75224
Harvey E. Ma1lory

P.O. Box 54696

Tulsa, Oklahoma 74155

Ed Martin

Superior Oil

Eastern Division

P.O. Box 51108 OCS

Lafayette, Louisiana 70505

Gene Polk

NL Baroid

6400 Uptown B1vd. N.E., $365 \mathrm{~W}$

Albuquerque, New Mexico 87110

De1 E. Pyle

Union Geothermal Division

Union Oil Co. of California

Union 0il Center

Los Angeles, California 90017

John C. Rowley

Los Alamos National Labs

Mai1 Stop 570

Los Alamos, New Mexico 87545

William D. Rumbaugh

Research \& Development

Otis

P. O. Box 34380

Dallas, Texas 75234

Dwight Smith

Halliburton

Drawer 1431

Duncan, Ok1ahoma 73533

Tom Warren

Amoco Production Company

Research Center

P. O. Box 591

Tulsa, Oklahoma 74102 


\section{DISTRIBUTION cont.}

Brian Doherty (5)

Foster-Miller, Inc.

350 Second Avenue

WaItham, Massachusetts 02254

U.S. Department of Energy

Geothermal Hydropower

Technologies Division

Forrestal B1dg., CE 324

1000 Independence Ave., S.W.

Washington, D.C. 20585

Attn: J. Bresee

D. Clements

R. Toms

D. A11en

G. E11is

Fred L. Goldsberry

U.S. Department of Energy

Geopressure Projects Office

Suite 8620 , Federal Bldg.

515 Rusk Street

Houston, Texas 77002

3141 L. J. Erickson

3151 W. L. Garner

9000 G. A. Fowler

9700 E. H. Beckner

9730 W. D. Weart

9740 R. K. Traeger

9741 J. R. Kelsey

9741 B. C. Caskey

9743 H. C. Hardee

9746 B. Granoff

9747 P. J. Hommert

9750 V. L. Dugan

9760 R. W. Lynch

9770 G. E. Brandvold

9780 R. M. Jefferson

8214 M. A. Pound 